\title{
On some common and new cavum-bearing Planothidium (Bacillariophyta) species from freshwater
}

\author{
Carlos E. WetzeL ${ }^{1 *}$, Bart VAn DE ViJver ${ }^{2,3}$, Saúl BlanCO $^{4}$ \& Luc Ector $^{1}$ \\ ${ }^{1}$ Luxembourg Institute of Science and Technology (LIST), Environmental Research and Innovation Department \\ (ERIN), 41 rue du Brill, L-4422 Belvaux, Luxembourg; *Corresponding author e-mail: carlos.wetzel@list.lu \\ ${ }^{2}$ Meise Botanic Garden, Research Department, Nieuwelaan 38, B-1860 Meise, Belgium \\ ${ }^{3}$ University of Antwerp, Department of Biology, ECOBE, Universiteitsplein 1, B-2610 Wilrijk, Antwerpen, Belgium \\ ${ }^{4}$ Diatom Lab. IMARENABIO, La Serna 58, 24007 León, Spain
}

\begin{abstract}
Thirteen Planothidium species are illustrated and discussed in a detailed morphological account based on light and scanning electron microscopy analysis of modern and historic materials related to the names Planothidium rostratum (Østrup) Lange-Bertalot and Planothidium frequentissimum (Lange-Bertalot) LangeBertalot. Eight species from freshwater environments in Europe, Asia and South America are proposed as new. All taxa here discussed and illustrated belong to the group of species characterized by the presence of a cavum in the rapheless valve. Additional information concerning their distribution and ecology is briefly commented based on a thorough literature revision.
\end{abstract}

Key words: Taxonomy, new species, Planothidium, Achnanthes, Achnanthidiaceae, morphology, type material

\section{INTRODUCTION}

The so-called 'monoraphid' diatoms belonging to the family Achnanthidiaceae D.G.Mann, Order Cocconeidales E.J.Cox (after Cox 2015) are characterized by having solitary cells or living in short chains, slightly curved in girdle view and by their heterovalvar condition, with a concave raphid valve and a convex rapheless valve. They are among the most common taxa inhabiting freshwater ecosystems. Hundreds of names have been formerly published within (or transferred to) the genera Achnanthes Bory [currently under the Order Mastogloiales D.G.Mann, after Cox \& Williams (2000) and Cox (2006)] and Achnanthidium Kützing, including species, subspecies, varieties and forms (LANGE-BERTALOT \& Krammer 1989; KocioleK et al. 2018).

The genus Achnanthes sensu lato has been partially revised in the past 30 years and is now split into several smaller genera that for freshwaters are included mainly in the family Achnanthidiaceae D.G.Mann. Ultrastructural studies of cell frustules during the 90's and posteriorly by means of scanning electron microscopy have allowed the split of Achnanthes into several new genera, such as Gliwiczia Kulikovskiy, Lange-Bertalot et Witkowski, Haloroundia C.A.Díaz et Maidana, Karayevia Round et Bukhtiyarova, Kolbesia Round et Bukhtiyarova, Lemnicola Round et Basson, Pauliella Round et Basson, Planothidium
Round et Bukhtiyarova, Platessa Lange-Bertalot and Skabitschewskia Kulikovskiy et Lange-Bertalot, while the genus Achnanthidium Kützing was sub-divided into Crenotia A.Wojtal, Psammothidium Bukhtiyarova et Round and Rossithidium Bukhtiyarova et Round. Hence, many taxa originally described as Achnanthes have been transferred to more suitable genera, so that Achnanthes sensu stricto remains mostly to designate robust, halophilous (marine to freshwater), and aerophytic forms similar to the generitype Achnanthes adnata Bory $(=A$. brevipes C.Agardh) and its allies (Cox 2006; ToFILOvsKA et al. 2014; MAJEWSKA et al. 2017).

The genus Planothidium was first proposed by Round \& BuKhTIYAROVA (1996) for species around Achnanthes lanceolata (Brébisson ex Kützing) Grunow in Cleve \& Grunow ( $\equiv$ Achnanthidium lanceolatum Brébisson ex Kützing), currently comprising up to 113 names according to KocioleK et al. (2018). Planothidium lanceolatum (Brébisson ex Kützing) Lange-Bertalot is by far the most frequent and widely cited diatom of this genus in continental waters worldwide (VAN DE VIJVER et al. 2013). The genus is predominantly epilithic or epipsammic and seems to be more diversified in alkaline environments. Several, but not all, Planothidium species are characterized in having an asymmetrical central area on the rapheless valve (see Morales 2006; JAHN et al. 2017). Internally, this central area bears a rimmed 
depression (named sinus), and in some cases, a hood (also known as cavum). The structure of the rimmed depression and hood were not recognized until examination under the scanning electron microscope by Moss \& CARTER (1982). Recent molecular studies highlight the differentiation between the two major clades within Planothidium (JAHN et al. 2017) based on the presence of the asymmetrical area.

In recent years many new Planothidium species have been better circumscribed or described as new, either using molecular or morphological methods or both (e.g. Potapova 2012; Álvarez-Blanco \& Blanco 2013; KUliKovsKIY et al. 2013, 2015; VAN DE VIJVER et al. 2013, 2018; WETZEL et al. 2013, 2014; N'GUESSAN et al. 2014; WETZEL \& ECTOR 2014a, b; ZIMMERMANN et al. 2014; BuKHTIYAROVA 2017; JAHN et al. 2017). Within the infraspecific taxa of Planothidium lanceolatum, Achnanthes lanceolata var. rostrata Hustedt is an abundant and putative cosmopolite variety in both lotic and lentic ecosystems, commonly reported in diatom floristic lists and inventories around the world. The main difference with respect to the nominal variety is the shape of the valve apices, which are clearly protracted in the variety rostrata. Despite this, a confusing nomenclatural and taxonomic history is tied to this name usually regarded as a catch-all species-complex.

Following the revision of type materials from historical collections, this manuscript aims to present a taxonomic and nomenclatural reappraisal of Achnanthes rostrata Østrup and "Achnanthes lanceolata var. dubia f. minuta" Grunow (namely Planothidium rostratum and Planothidium frequentissimum, respectively) based on the examination of original materials using light (LM) and scanning electron microscopy (SEM). A re-interpretation of the complex is proposed and eight species are described as new.

\section{Material ANd Methods}

Type slides and unmounted type material were examined using LM and SEM. Original material from the Van Heurck collection [Botanic Garden Meise (BR), Belgium], Hustedt collection [Alfred-Wegener-Institut für Polar- und Meeresforschung (BRM) Bremerhaven, Germany], the National Museum of Nature and Science (TNS), Tsukuba, Japan]), the Østrup collection [Botanical Garden of Copenhagen (C), Denmark] and the Musée d'Histoire Naturelle La Chaux-de-Fonds [(CH), Neuchâtel, Switzerland)] was used. Herbarium acronyms follow THIERs et al. [continuously updated]. The term "original material" is used here according to the International Code of Nomenclature for algae, fungi, and plants (TURLAND et al. 2018). The symbols "三” and "=" before the names of specific and infraspecific taxa are used to represent homotypic or nomenclatural, and heterotypic or taxonomical synonyms, respectively. A third type of synonym which can be called a concept synonym is marked by "-"; this concerns invalid names, misapplied names and taxonomic synonyms which do not include the type of the name, following JAHN \& KUSBER (2009).

The materials listed in Table 1 were observed in LM and SEM. Samples were cleaned following standard procedures, i.e. treated by oxidation with hot $37 \%$ hydrogen peroxide $\left(\mathrm{H}_{2} \mathrm{O}_{2}\right)$ in a sand bath during 24 hours. Preparations were then allowed to cool and settle (ca. $1 \mathrm{~cm} \cdot \mathrm{h}^{-1}$ ), and 80 to $90 \%$ of the supernatant was eliminated by vacuum aspiration. A volume of $1 \mathrm{ml}$ of hydrochloric acid ( $\mathrm{HCl} \mathrm{37 \% )}$ was then added and the mixture was allowed to rest for $2 \mathrm{~h}$ followed by three repetitions of rinsing and decantation using deionized water. Diatom slides were made in accordance with the French diatom protocol (AFNOR 2007). For scanning electron microscopy, parts of the oxidized suspensions were filtered and rinsed with additional deionized water through a $3 \mu \mathrm{m}$ Isopore ${ }^{\mathrm{TM}}$ polycarbonate membrane filter (Merck Millipore). Filters were mounted on aluminium stubs and coated with platinum using a BAL-TEC MED 020 Modular High Vacuum Coating System for 30 seconds at $100 \mathrm{~mA}$. An ultra-high-resolution analytical field emission (FE) scanning electron microscope Hitachi SU-70 (Hitachi High-Technologies Corporation, Tokyo, Japan) operated at $5 \mathrm{kV}$ and $10 \mathrm{~mm}$ distance was used for the analysis. SEM images were taken using the lower (SE-L) detector signal. Photomicrographs were digitally manipulated and plates containing light and scanning electron microscopy images were created using CorelDraw $X 8^{\circledR}$. Type materials of the newly described species were deposited at the Meise Botanic Garden (BR, Belgium). Basic morphometric variables were measured using Leica Application Suite ${ }^{\mathfrak{O}}$ : length (L) $(\mu \mathrm{m})$, width $(\mathrm{W})(\mu \mathrm{m})$, length/width ratio $(\mathrm{L}: \mathrm{W})$ and number of striae in $10 \mu \mathrm{m}$.

\section{RESUlTS AND DiscuSSION}

This section can be roughly divided into two main subsections based on the valve morphology: the first subsection (Figs 1-246) deals with all rostrate species belonging to the Achnanthes rostrata Østrup complex and discusses the changing concepts of the taxa defined by HusTEDT (1911) as Achnanthes lanceolata var. rostrata Hustedt, from Germany, based on his drawings (Figs 2-4) and specimens found in Hustedt's original material (Figs 5-10). The second subsection (Figs 247-521) deals with species having a rounded to elliptical valve morphology grouped under Planothidium frequentissimum (Lange-Bertalot) Lange-Bertalot (Figs 250-282) and similar taxa. The list of species illustrated and discussed is shown in Table 2.

\section{Planothidium rostratum (Østrup) Lange-Bertalot in LANGE-Bertalot (1999) (Figs 11-61, LM; 109-119, SEM)}

$\equiv$ Achnanthes rostrata Østrup in ØSTRUP (1902, p. 35); - Planothidium rostratum (Østrup) Round et Bukhtiyarova in Round et BuKHTIYAROva (1996, p. 352) comb. inval.; - Achnantheiopsis rostrata (Østrup) Lange-Bertalot in LANGE-BERTALOT (1997, p. 208) nom. illeg.

LM (Figs 11-61): Valves elliptical. Shorter specimens with shortly rostrate ends, while longer ones having longer rostrate ends. Length $6.5-15.0 \mu \mathrm{m}$, width 4.0-6.5 $\mu \mathrm{m}$. Rapheless valves (Figs 11-18, 23-31, 36-48): axial area narrow, straight, linear. Central area with a unilateral large horseshoe-shaped hyaline area with a clearly visible cavum. On the opposite side, striae never shortened, always reaching the axial area. Striae weakly 
radiate throughout the entire valve, $12-14$ in $10 \mu \mathrm{m}$, measured at the central part of the valve opposite to the cavum. Raphe valve (Figs 19-22, 32-35, 49-61): axial area narrow, linear, widening towards the central area. Central area rectangular to slightly rounded, bordered on each side by usually two, but up to three shortened striae. Fascia absent. Raphe branches straight with expanded, drop-like proximal raphe endings. Distal raphe fissures unilaterally deflected. Striae radiate throughout the entire valve, $12-16$ in $10 \mu \mathrm{m}$.

SEM (Figs 109-119): Rapheless valve (Figs 109-115): striae composed externally of three to four rows of small, rounded areolae (Figs 109-113), the middle two rows being slightly smaller than the outer two parallel rows. Striae near the axial area often composed of three rows of areolae. Near the valve mantle, striae occasionally composed of four areolae. Striae mostly discontinuing on the valve mantle. Areolae on the valve mantle usually composed of groups of four to five, the last one being longer than the others (Figs 109, 110). Irregular, shallow, slit-like depressions present in the central and axial area (Figs 109-113). Internal cavum aperture narrow (Fig. 115). Raphe valve (Figs 116-119): striae broader than the virgae, composed of three to four rows of rounded areolae (Figs 116, 117). Striae internally sunken between raised virgae (Figs 118, 119). Areolae internally covered by individual hymenes (Fig. 118). Proximal external raphe endings straight, terminating in expanded pores (Figs 116, 117). Terminal raphe fissures unilaterally bent, continuing shortly onto the valve mantle (Figs 116, 117). Internally central nodule raised, with proximal raphe endings slightly deflected to opposite sides (Figs 118, 119), terminating inconspicuously (Figs $118,119)$. Terminal raphe endings terminating on faint helictoglossae (Fig. 118).

Type: THAILAND. Koh Chang Island, Klong Sarlakpet, as Achnanthes rostrata slide $\mathrm{n}^{\circ} 3293$ in Copenhagen Botanical Garden (C).

Additional observed material (LM and SEM): INDONESIA. Sumatra, Balige, Lake Toba. Sample AS855 (BRM); INDONESIA. Sumatra, Lake Toba. Sample AS865 (BRM), both materials housed at HuSTEDT collection, Bremerhaven (BRM).

Taxonomic remarks: Described originally from Thailand (Koh Chang Island, ancient 'Siam') at the 'Klong Sarlakpet' locality, the original slide number "3293" (C) of Achnanthes rostrata Østrup (here reproduced as Fig. 1) was 'resurrected' by Moss \& CARTER (1982, fig. 7) who presented the first image of the original material from Thailand after its original description. They wrote on the significance of the cavum, until then a poorly understood character among "Achnanthes" taxa. LANGE-BERTALOT \& Krammer (1989, pl. 85, figs 3-6) photographed the “Typenpräp. Coll. Oestrup 3314" and identified some specimens as Achnanthes rostrata. Two years later, the same images were presented as "lectotype from Siam" by KrAMMER \& LANGE-BERTALOT (1991, pl. 43, figs 1-4) who placed the images together with several additional populations (North American and European) under "Achnanthes lanceolata-Sippenkomplex". In the latter the use of the infraspecific epithets 'rostrata' and 'frequentissima' in different positions (i.e. Achnanthes lanceolata ssp. rostrata and "Achnanthes lanceolata ssp. frequentissima var. rostrata") was not in agreement with the nomenclature (ICN art. 6.4) as correctly noted by COMPÈRE (1991), making these names invalid or superfluous (illegitimate) (see LANGE-BERTALOT \& KrAmmer 1989 on the " Falsche dubia/rostrata-Sippen"). However, after the re-arrangements made posteriorly by LANGE-BERTALOT (1993) for "Achnanthes lanceolata ssp. frequentissima var. rostratiformis" Lange-Bertalot, the names continued to be illegitimate. The mentioned names were based on a variety described by HUSTEDT (1911, p. 279, pl. 3, fig. 34 a-b), i.e. Achnanthes lanceolata var. rostrata Hustedt, who regarded the species as a transitional form ("Uebergangsform zwischen") between Achnanthes lanceolata Brébisson and the 'variety dubia Grunow'. Hustedt's brief Latin description ("valva elliptica apicibus rostratis, subcapitatis") and the accompanying drawing (here reproduced as Fig. 2) does not fit into the current concept of this taxon, clearly referring to an entirely different species belonging to the recently erected genus Skabitschewskia. The valve outline in A. lanceolata var. rostrata sensu HuSTEDT (1911) can hardly be regarded as elliptic (in the sense used by Hustedt), but rather broadly elliptic, as shown by HustedT (1930) himself in his revision of the taxon. The concepts of Achnanthes lanceolata var. rostrata in Hustedt $(1930,1959)$ are here reproduced in Figs 3 and 4 respectively. Moreover, the apices are rarely subcapitate. Given the shape and size of the cavum and the central area, the iconotype illustrated in the protologue can be ascribed to certain individuals found in the type material (Figs 5 and 6) who, in turn, are clearly identifiable as Skabitschewskia peragalloi (Brun et Héribaud) Kulikovskiy et Lange-Bertalot. Hustedt most likely (maybe years after his original description in 1911) marked one specimen in the type slide, a different one from what the actually described, that was selected as lectotype by SimONSEN (1987) who indeed noted the lack of correspondence with the iconotype (op. cit., p. 20 ). Independently of the history and confusion that might have been created following the lectotypification of Achnanthes lanceolata var. rostrata, and the recommendations of the ICN that were ignored by SIMONSEN (1987) and posteriorly by BĄK \& LANGE-BERTALOT (2014) (i.e. recommendation 9A.3), the type material from Borgfeld (Wümme River, Bremen, E911 BRM!) containing the specimens illustrated by SimONSEN (1987, pl. 4, figs 6,7) is nowadays the lectotype for a species named Planothidium rostratoholarcticum Lange-Bertalot et Bąk in BĄK \& LANGE-BERTALOT (2014). Indeed, the specimens found in the material E911 (here illustrated 


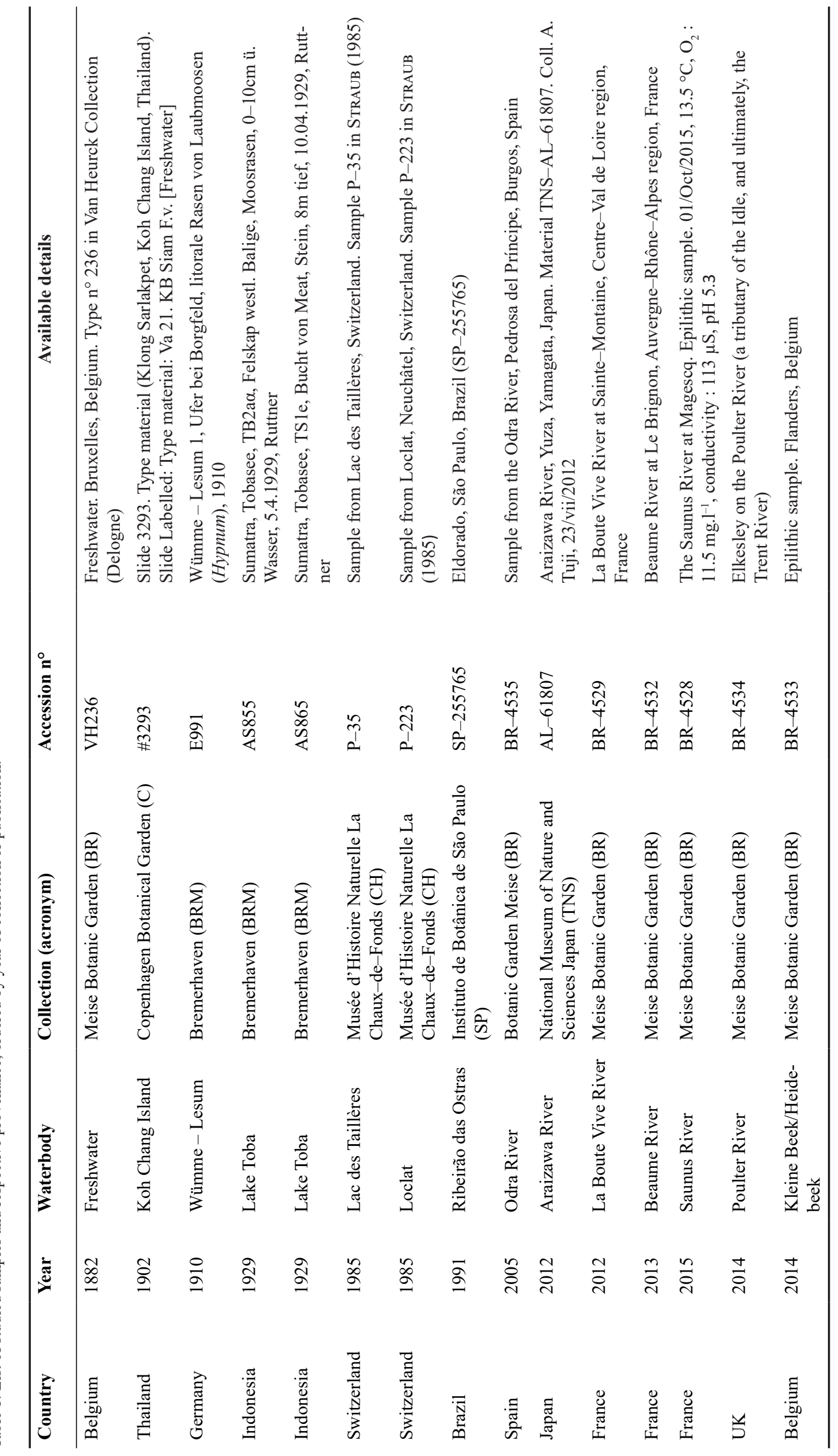


for the first time in SEM in the Figures 7-10) agree with the concept that Holarctic species differ from the Tropical ones when considering the number of areolae in the striae (2-3 compared to 4 , as discussed later in this manuscript). Since the original Østrup material from Thailand was not available for SEM, we decided to emend the diagnosis containing its ultrastructural characterization that could correspond to the original material from Thailand, based on material from Indonesia (Lake Toba, Sumatra).

Planothidium rostratoholarcticum Lange-Bertalot et Bąk in BąK et LANGE-BERTALOT (2014) (Figs 62-108, LM; 120-139, SEM)

- Achnanthes lanceolata var. rostrata Hustedt in HustedT (1911, p. 279) sensu SimONSEN (1987, p. 20, pl. 4, figs 6, 7); - Achnanthes lanceolata var. rostrata (Østrup) Hustedt in HustedT (1930, p. 208); Achnanthes lanceolata f. rostrata (Østrup) Hustedt in HustedT (1957, p. 251); - Achnanthes lanceolata ssp. rostrata (Østrup) Lange-Bertalot in KrAmmer \& LANGE-Bertalot (1991, pl. 43, figs 1-4); - Achnanthes lanceolata ssp. frequentissima var. rostratiformis Lange-Bertalot in LANGE-Bertalot (1993, p. 5) comb. inval.

LM (Figs 65-108): Valves elliptical with only weakly elongated apices, usually more broadly protracted, subrostrate rather than rostrate, even in the largest specimens. Length 6.4-13.5 $\mu \mathrm{m}$, width 3.8-6.4 $\mu \mathrm{m}$. Rapheless valves (Figs 65-79, 86-104): axial area narrow, straight, linear. Central area having a unilateral, large, horseshoe-shaped hyaline area with a cavum. On the opposite side, striae not shortened, always reaching the axial area. Striae weakly radiate throughout the entire valve, $13-17$ in 10 $\mu \mathrm{m}$, measured at the central part of the valve opposite to the cavum. Raphe valve (Figs 80-85, 105-108): axial area narrow, linear. Central area irregular, bordered on each side by usually one shortened stria. Fascia absent.
Raphe branches straight with expanded, drop-like proximal raphe endings. Terminal raphe fissures unilaterally deflected. Striae radiate throughout the entire valve, 14-17 in $10 \mu \mathrm{m}$.

SEM (Figs 120-139): Rapheless valve (Figs 120-126, 131-136): striae composed externally of two to three (rarely four near the valve edges, see Fig. 122) rows of small, rounded areolae (Figs 120-123), with the middle row being slightly smaller than the two parallel outer rows (Fig. 120) or with even size (Fig. 131). Striae continuing on the valve mantle/face junction. Striae on the valve mantle composed usually of groups of two to three areolae; the last one being slightly elongated (Figs 120, $122,131,132)$. Irregularly orientated shallow, slit-like depressions present mainly in the central and axial area (Figs 120-123, 131-134). Internal cavum aperture relatively wide (Figs 124-126, 135, 136). Virgae strongly raised between the striae. Raphe valve (Figs 127-130, 137-139): striae broader than the virgae, composed of two to three rows of rounded areolae (Figs 127, 128, $137,138)$. Striae internally sunken between raised virgae (Figs 129, 130, 139). Areolae internally covered by individual hymenes (Figs 129, 139). Proximal external raphe endings straight, terminating in expanded pores (Figs 127, 128, 137, 138). Terminal raphe fissures unilaterally bent, continuing shortly onto the valve mantle. Internally central nodule raised, with proximal raphe endings slightly deflected to opposite sides (Figs 129, $130,139)$. Terminal raphe endings terminating on faint helictoglossae.

Type: GERMANY. Wümme River, Borgfeld (Bremen) epiphyte on Hypnum. Sample E991. Slide 212/73 in Hustedt Collection (BRM).

Table 2. List of species and cross-referenced figures (LM, SEM).

Species

Figures

Planothidium alekseevae Gogorev et Lange

$186-199,231-238$

Planothidium brasiliense C.E.Wetzel et S.Blanco sp. nov.

Planothidium cavilanceolatum C.E.Wetzel, M.G.Kelly et Van de Vijver sp. nov.

$464-514,515-521$

Planothidium curtistriatum C.E.Wetzel et Ector sp. nov.

$386-414,444-456$

Planothidium frequentissimum (Lange-Bertalot) Lange-Bertalot

$251-282,344-353$

Planothidium gallicum C.E.Wetzel et Ector sp. nov.

$164-185,224-229$

Planothidium hinzianum C.E.Wetzel, Van de Vijver et Ector sp. nov.

$415-439,457-463$

Planothidium potapovae C.E.Wetzel et Ector sp. nov.

200-210, 239-246

Planothidium rostratoholarcticum Lange-Bertalot et Bąk

$62-108,120-139$

Planothidium rostratum (Østrup) Lange-Bertalot

$11-61,109-119$

Planothidium straubianum C.E.Wetzel, Van de Vijver et Ector sp. nov.

$362-385,440-443$

Planothidium tujii C.E.Wetzel et Ector sp. nov.

$140-163,218-223$

Planothidium victori Novis, Braidwood et Kilroy

$283-343,354-361$ 
Taxonomic remarks: Achnanthes rostrata underwent a complex nomenclatural history and only recently BĄK \& LANGE-BERTALOT (2014) partially settled the issue with the description of $P$. rostratoholarcticum. SCHULZ (1926) considered this taxon being the variety Achnanthes lanceolata var. rostrata Schulz in ScHULz (1926, p. 192, fig. 23a, b, nom. illeg. (as "Achnanthes lanceolata var. rostrata Hustedt?"). The name was again proposed by Hustedt (1957) as A. lanceolata var. rostrata (Østrup) Hustedt, but these names were all illegitimate since all of them are later homonyms of $A$. lanceolata var. rostrata Hustedt. Formerly, ScHulz also transferred $A$. rostrata to Microneis as M. lanceolata var. rostrata (Østrup) Schulz, though this combination may be invalid according to KocIOLEK et al. (2018). The binomen "Achnanthidium rostrata" appeared in MiLls (1933) as a mistake so the combination was neither valid nor accepted by Mills. Cleve-Euler (1953) invalidly published "A. haynaldii 'eta' borussica (sic)" as a new name for A. lanceolata var. rostrata sensu ScHULZ (1926), with no clear indication of rank. KRAMMER \& LANGE-BERTALOT (1991) placed this taxon to subspecies level within $A$. lanceolata, proposing $A$. lanceolata subsp. rostrata. This combination was purportedly validated in LANGE-BERTALOT (1993) where the place of publication of the basionym is entirely cited but became again illegitimate by homonymy with Hustedt's taxon. Round \& BukHTIYAROva (1996) raised the variety to species level combining it with Planothidium as $P$. rostratum, but cited incorrectly the basionym, so the name is considered again invalid in SiLva (2010). However, such citation errors do not prevent valid publication of new combinations (ICN, Art. 41.8, Turland et al. 2018). This situation was corrected by LANGE-BERTALOT (1999) proposing Planothidium rostratum (Østrup) Lange-Bertalot, a later isonym of Round et Bukhtiyarova's combination. Formerly, LANGE-BERTALOT (1997) had also combined the taxon into the superfluous genus Achnantheiopsis as Achnantheiopsis rostrata (Østrup) Lange-Bertalot. Contrary to $A$. lanceolata var. rostrata, the name $P$. rostratum (as Achnanthes rostrata) has been profusely investigated and illustrated (e.g., GASSE 1980; LoSEVA 1982; Moss \& CARTER 1982; FABRI \& LeClercQ 1984; Straub 1985; Round \& BukHTIYARova 1996; Cocquyt 1998).

Confusion between Hustedt and Østrup taxa may have arisen from the proposal in widely known floristic works of $A$. rostrata Østrup as a presumable synonym of $A$. lanceolata var. rostrata Hustedt (see KRAMMER \& LANGE-Bertalot 1991; LANGE-Bertalot 1997), thus conferring nomenclatural priority to $A$. rostrata. This has been suggested by Moss \& CARTER (1982) and LowE \& Cody (2002) who stated that Hustedt, in the protologue dated on 1911, just reduced Østrup's A. rostrata to a varietal status within $A$. lanceolata. However, HuSTEDT (1911) described a clearly new taxon based on his own material. This transfer was never followed in any of the other Hustedt works (HuSTEDT 1930, 1959) as mentioned in the discussion LANGE-BERTALOT \& KRAMMER (1989) added on this topic. HustedT (1930) only presented $A$. lanceolata var. rostrata Hustedt "as a transitional form or synonym of [...] A. rostrata Østrup".

Moss \& CARTER (1982) presented an emended description of $A$. lanceolata and $A$. rostrata based on the examination of original materials, re-establishing Østrup species on the basis of the presence of a true cavum (and not a sinus) in the rapheless valve as a main differential character, although this discrimination was later criticized by KRAMMER \& LANGE-BERTALOT (1991) who had observed transitional forms between both structures in this clade, hence rejecting also the infraspecific classification proposed by STRAUB (1985, 1990) of morphotypes belonging to A. rostrata following Moss \& Carter's work.

KRAMMER \& LANGE-Bertalot (1991, p. 334) proposed to differentiate these taxa based on the presence of up to three rows of areolae in the rapheless valve of $A$. lanceolata var. rostrata and four or more in A. rostrata. Finally, LANGE-BERTALOT (1993) clearly separated both taxa placing them in different subspecies within A. lanceolata on the basis of their different valvar ultrastructure and biogeography, though their distribution areas overlap in America. Indeed, our observations on the type material of $A$. lanceolata var. rostrata from the Wümme River (i.e. P. rostratoholarcticum) corroborate the presence of 2-3 rows of areolae in the striae in populations from Europe (Germany, Spain and Switzerland) (Figs 120-139) compared to the Asiatic populations (Figs 109-119) which are usually formed by up to four rows of areolae hence decreasing slightly the number of striae on the valve due to the larger dimensions of each stria and narrower virga.

Finally, the long confusion concerning the typification of the "rostrata" name recently ended with the publication of $P$. rostratoholarcticum replacing Achnanthes lanceolata var. rostrata Hustedt in HusTEDT (1911, p. 279 , pl. 3, fig. $34 \mathrm{a}-\mathrm{b}$ ) and excluding the synonym of Achnanthes rostrata Østrup in ØSTRUP (1902). LANGEBeRTALOT (1993) definitively classified var. rostrata under subsp. frequentissima, proposing $A$. lanceolata subsp. frequentissima var. rostratiformis Lange-Bertalot to name this taxon. The epithet "rostratiformis" was explicitly elected to avoid homonymy with $A$. lanceolata subsp. rostrata (Østrup) Lange-Bertalot in KRAMMER \& LANGE-BERTALOT (1991), validated in the same work but based in a different taxon (A. rostrata). This combination became illegitimate under ICN Art. 11 (see also Art. 26 and Art. 53.3) (TuRLAND et al. 2018), as stated in KocioleK et al. (2018), since it represents a superfluous new name to replace an earlier, valid one. Moreover, the placing of var. rostrata under subsp. rostratiformis does not constitute a change in nomenclatural status. Finally, Achnanthes lanceolata f. rostrata Esyreva, published in 1945 , is also a later homonym for this taxon. 
Planothidium tujii C.E.Wetzel et Ector sp. nov. (Figs 140-163, LM; 218-223, SEM)

LM (Figs 140-163): Valves lanceolate to broadly elliptic-lanceolate with convex margins and rostrate apices. Valve dimensions: length 13.0-14.5 $\mu \mathrm{m}$, width 5.0-6.0 $\mu \mathrm{m}$. Rapheless valve (Figs 140-151): axial area narrow, linear, slightly expanded in the central area opposite to the widely open cavum. Striae weakly radiate throughout the entire valve, 14-16 in $10 \mu \mathrm{m}$, measured at the central part of the valve opposite to the cavum. Raphe valve (Figs 152-163): axial area narrow, linear, widening near the central area. Central area rectangular to slightly round bordered on each side by usually two shortened striae. Raphe branches straight with expanded, drop-like proximal raphe endings.

SEM (Figs 218-223): Rapheless valve (Figs 218-221): striae composed externally of three to four rows of small rounded areolae. Striae located at the central area becoming narrower towards the axial area (Figs 218, 219) continuing shortly on the valve mantle. Irregular and shallow rounded depressions present along the axial area and concentrated in the central area (Figs 218, 219) as well as on the virgae. Cingulum composed of unperforated copulae. Internally, cavum with a prominent aperture towards the mantle (Figs 220, 221); areolae covered by individual hymenes (Figs 220, 221). Raphe valve (Figs 222, 223): striae externally having about the same size as the virgae, composed of usually four (down to two) rows of rounded areolae (Fig. 222). Shortened central striae gradually narrower towards the axial area (Fig. 222). External raphe straight, with proximal ends showing expanded pores (Fig. 222). Distal raphe fissures unilaterally bent, continuing shortly onto the valve mantle (Fig. 222). Proximal raphe endings internally deflected to opposite sides (Fig. 223). Terminal raphe endings terminating on faint helictoglossae, shortly continuing on the valve mantle (Fig. 223).

Type: JAPAN. Yamagata Prefecture, Yuza, River Araizawa. Material TNS-AL-61807 illustrated in Algae Aquae Dulcis Japonicae Exsiccatae (Tuj 2014, p. 15, prep. ${ }^{\circ} 114$ ). Slide prepared from strain Ak807 at National Museum of Nature and Science (TNS), Tsukuba, Japan (TNS).

Etymology: The species is dedicated to Dr. AKIHIRO TuJi (National Museum of Science and Nature, Tsukuba, Japan) who kindly sent us the material from Japan.

Taxonomic remarks: Planothidium tujii was identified as Planothidium rostratum apud TuJI (2014, p. 15, prep. $\mathrm{n}^{\circ} 114$ in Algae Dulcis Japonicae Exsiccatae, Fasc. VI). We consider the differences on broader and elliptic valves, along with a finer and more delicate striation patterns as sufficient to justify the separation of $P$. tujii from $P$. rostratum and $P$. rostratoholarcticum whose cells show a more squared morphological outline. Moreover, the valve surface patterns (i.e. irregularly shallow rounded depressions) render the species more similar to the species-complex around $P$. frequentissimum, $P$. victori and $P$. naradoense [see JAHN et al. 2017, figs 236, 345 and 368, respectively and ZimMERMANN et al. 2014, fig. 3d for $P$. caputium]. Both P. rostratum and P. rostratoholarcticum present instead irregular lines along the axial area and scattered along the central area.

Planothidium gallicum C.E.Wetzel et Ector sp. nov. (Figs 164-185, LM; 224-229, SEM)

- Achnanthes lanceolata (Brébisson) Grunow apud Lange-BerTalot \& Krammer (1989, pl. 85, figs 1, 2); - Achnanthes lanceolata ssp. biporoma (Hohn et Hellerman) Lange-Bertalot apud Krammer \& LANGe-Bertalot (1991, pl. 43, figs 33, 34).

LM (Figs 164-185): Valves lanceolate to broadly elliptic-lanceolate with convex margins and rostrate apices. Valve dimensions: length 14.0-17.0 $\mu \mathrm{m}$, width 5.5-6.5 $\mu \mathrm{m}$. Rapheless valve (Figs 164-174): axial area narrow, linear, slightly expanded in the central area opposite to the cavum. Central area with a unilateral, large, horseshoe-shaped, hyaline area with a clearly visible cavum. Striae weakly radiate throughout the entire valve, 14-18 in $10 \mu \mathrm{m}($ mean $=15)$, measured at the central part of the valve opposite to the cavum. Raphe valve (Figs 175-185): axial area narrow, linear, widening near the central area, the latter irregularly rectangular, usually bordered on each side by two shortened striae. Fascia never present. Raphe branches straight with expanded, drop-like proximal raphe endings.

SEM (Figs 224-229): Valve mantle shallow. Rapheless valve (Figs 224-227): striae composed externally of three to four rows of small rounded areolae (Figs 224, 225). The striae located at the central area (i.e. not becoming narrower towards the axial areal. Striae continuing shortly on the valve mantle (Fig. 224). Internal areolae covered by individual hymenes (Figs 226, 227). Irregular, shallow rounded depressions present along the axial area and concentrated near the central area (Figs 224, 225). Virgae usually narrower towards the apices. Cingulum composed of open, unperforated copulae (Fig. 225). Internally, cavum with a prominent aperture towards the mantle (Figs 226, 227). Raphe valve (Figs 228, 229): striae having about the same size as the virgae in the middle of the valve, composed of usually four rows of rounded areolae (Fig. 228). Two to three shorter central striae present at the central area (Fig. 228). Proximal external raphe endings straight, terminating in expanded pores (Fig. 228). Terminal raphe fissures unilaterally bent, continuing shortly onto the valve mantle (Fig. 228). Internally, raphe valve having a slightly raised central nodule, with proximal raphe endings deflected to opposite sides (Fig. 229). Terminal raphe endings terminating on faint helictoglossae (Fig. 229).

Type: FRANCE. Saunus River at Magescq, Landes department in Nouvelle-Aquitaine, south-western 
France. Slide BR-4528 deposited at Meise Botanic Garden (Belgium).

Etymology: We refer to Gallia (English: Gaul), a region of Western Europe during the Iron Age occupied nowadays mostly by France and Belgium.

Taxonomic remarks: - Images of Planothidium gallicum were published within the "Achnanthes lanceolata (Brébisson) Grunow (sensu latissimo)" by LANGEBertalot \& Krammer $(1989$, pl. 85, figs 1, 2) from a population collected in Finland. The same images were published afterwards as Achnanthes lanceolata ssp. biporoma (Hohn et Hellerman) Lange-Bertalot sensu Krammer \& LANGE-Bertalot (1991, pl. 43, figs 33, 34). The most similar is Planothidium tujii from which it differs mainly in having a higher stria density and slightly wider cells (Fig. 230). The more pronounced rostrate apices also add to the differences between the European (P. gallicum) and the Asiatic species (P. tujii). A thorough discussion on the identity of Planothidium biporomum complex based on type materials was published in Wetzel et al. (2013).

Planothidium alekseevae Gogorev et Lange in Gogorev \& LANGE (2015) (Figs 186-199, LM; 231-238, SEM) - Achnanthes rostrata Østrup 'type capité' (type morphologique r5) apud Straub (1985, pl. 4, fig. 57; pl. 6, fig. 87; pl. 7, figs 101, 102); - Achnanthes lanceolata ssp. biporoma (Hohn et Hellermann) Lange-Bertalot sensu Krammer \& LANGE-Bertalot (1991, pl. 43, figs 35-40).

LM (Figs 186-199): Valves lanceolate to elliptic-lanceolate with convex margins and rostrate apices. Valve dimensions: length 9.5-13.5 $\mu \mathrm{m}$, width $4.5-5.0 \mu \mathrm{m}$. Rapheless valve (Figs 186-197): axial area narrow, linear and slightly expanded in the central area opposite to the cavum. Central area having a unilateral large horseshoeshaped hyaline area with a clearly visible cavum. Striae weakly radiate throughout the entire valve, 14-16 in 10 $\mu \mathrm{m}$ (mean $=15)$, measured at the central part of the valve opposite to the cavum. Raphe valve (Figs 198, 199): axial area narrow, linear, widening near the central area, the latter irregularly rectangular, bordered on each side by one to two shortened striae. Raphe branches straight with expanded, drop-like proximal raphe endings.

SEM (Figs 231-238): Rapheless valve (Figs 231-233): striae composed externally of four (sometimes three near the axial area) rows of small rounded areolae (Figs 231, 232). Striae continuing shortly onto the valve mantle (Fig. 232). Valve surface rather smooth (Fig. 232) with only a few rounded depressions near the central area. Virgae narrow. Cingulum composed of open, unperforated copulae (Fig. 232). Internally, cavum with a prominent aperture, opening towards the mantle (Fig. 233). Raphe valve (Figs 234-238): striae slightly larger than the virgae in the middle of the valve, composed of usually four rows of rounded areolae (Figs 234-236). Up to two shorter striae surrounding the central area (Fig. 235). Proximal external raphe endings straight, terminating in expanded pores (Figs 234-236). Terminal raphe fissures unilaterally bent, continuing shortly onto the valve mantle (Figs 234, 236). Internally, raphe valve with slightly raised central nodule (Fig. 237). Proximal raphe endings deflected to opposite sides (Figs 237, 238). Terminal raphe endings terminating on faint helictoglossae (Fig. 237). Valve mantle relatively shallow. Two to three small areolae per striae found on the mantle.

Observed material: Switzerland. Lac des Taillères, Neuchâtel. Sample P-35, deposited at Musée d'Histoire Naturelle La Chaux-de-Fonds (CH).

Taxonomic remarks: Planothidium alekseevae was recently described by GoGOREV \& LANGE $(2015$, p. 15 , pl. 1, figs 1-15; pl. 2, figs 3-5) from the uppermost brackish-water layer of the subpolar meromictic Lake Mogilnoye (Kildin Island, Barents Sea, Russia). The species however, was illustrated for the first time in the literature by StRAUB (1985, pl. 6, fig. 87; pl. 7, figs $101,102)$ from a littoral epilithic sample from the Lac des Taillères (Switzerland), but placed in an infraspecific rank. Straub (1985) included the species within A. rostrata var. magna F.Straub 'race' or 'sippen r5', arguing that it would correspond, based on its dimensions and form to Achnanthes lanceolata var. capitata O.Müller. A recent revision of the types of Planothidium capitatum (O.Müller) Van de Vijver et al., Planothidium haynaldii (Schaarschmidt) Lange-Bertalot (WeTZEL et al. 2014) and P. biporomum (WeTZeL et al. 2013) allowed Gogorev \& LANGe (2015) to describe P. alekseevae and thus it should be considered as an independent and recognisable species. The sample from Lac des Taillères was also illustrated by KRAMMER \& LANGE-BERTALOT (1991, 2004, pl. 43, figs 35-40) within the P. biporomum complex and is detailed here in SEM. So far, the species has been observed in several localities in Russia by GenKal \& Trifonova $(2009$, p. 41, pl. 61, figs 8 , 9), GeNKAL et al. (2013, p. 69, pl. 26, figs 79-90) and Chudaev \& Gololobova (2016, pl. 129, figs 23-35). Additional observations include several populations in coastal rivers in Belgium (Van de Vijver, pers. obs.) and most likely also specimens illustrated by MetZeltin et al. $(2005$, pl. 34 , figs 15,16$)$ from Uruguay showing high similarity in LM.

Planothidium potapovae C.E.Wetzel et Ector sp. nov. (Figs 200-210, LM; 239-246, SEM)

- "Achnanthes lanceolata var. (?)" in LANGE-Bertalot \& Krammer (1989, pl. 86, figs 41-43); - Achnanthes lanceolata ssp. rostrata (Østrup) Lange-Bertalot sensu Krammer \& LANGE-BerTaLOT (1991, pl. 43, figs 12-14); = Planothidium rostratum (Østrup) Lange-Bertalot sensu PotAPOVA (2010) pro parte, , i.e. figs 1-3, LM.

LM (Figs 200-210): Valves lanceolate to broadly elliptic-lanceolate with strongly rostrate apices. Valve dimensions: length 11.5-14.5 $\mu \mathrm{m}$, width 5.0-6.0 $\mu \mathrm{m}$. 
Rapheless valve (Figs 200-207): axial area linearlanceolate widening considerably towards the central area. Striae weakly radiate throughout the entire valve, shorter near the central area, 12-14 in $10 \mu \mathrm{m}$ (mean = 13), measured at the central part of the valve opposite to the cavum. Raphe valve (Figs 208-210): axial area narrow with a wide rectangular central area bordered on each side by one to three shortened striae. Raphe branches straight with expanded, drop-like proximal raphe endings.

SEM (Figs 239-246): Rapheless valve (Figs 239-244): striae composed externally of four (sometimes three near the axial area) rows of small rounded areolae (Figs 239, 240). Striae continuing shortly onto the valve mantle (Fig. 239) by groups of up to nine areolae (two rows of 4 to 5 poroids, Fig. 243). Valve surface rather smooth with strongly marked irregular lines concentrated near the central area and along the axial area (Figs 239, 240). Virgae narrow. Cingulum composed of open, unperforated copulae (Fig. 245). Internally, cavum with a prominent aperture towards the mantle (Fig. 241). External raphe valve (Fig. 245) with lanceolate striae composed of four to two rows of rounded areolae. Central striae narrower towards the axial area. Proximal external raphe endings straight, terminating in expanded pores (Fig. 245). Terminal raphe fissures unilaterally bent, continuing shortly onto the valve mantle (Fig. 245). Internal raphe valve with slightly raised central nodule (Fig. 246). Proximal raphe endings deflected to opposite sides (Fig. 246). Terminal raphe endings terminating on faint helictoglossae (Fig. 246). Valve mantle relatively shallow. Two to three small areolae per striae observed at the mantle (Fig. 245).

Type: France. River La Boute Vive at Sainte-Montaine, Centre-Val de Loire region. Slide BR-4529 deposited at Meise Botanic Garden (Belgium).

Etymology: We dedicate this species to Dr. Marina Potapova (Academy of Natural Sciences, Drexel University, Philadelphia, USA).

Taxonomic remarks: The new species is separated from $P$. rostratum and $P$. rostratoholarcticum based on its distinct wide central area on both valves. An additional difference can be found in its striae showing up to five rows of areolae on the valve mantle. The species has been included in the rostratum complex and was previously illustrated by LANGE-BERTALOT \& KRAMMER (1989, pl. 86, figs 41-43) as “Achnanthes lanceolata var. (?)" from Firehole River (Yellowstone, USA) and as Achnanthes lanceolata ssp. rostrata (Østrup) Lange-Bertalot by KRAMMER \& LANGE-BERTALOT (1991, pl. 43, figs 12-14, pro parte). Similar populations are currently illustrated by Potapova (2010) in the Diatoms of USA web site and PeEters \& ECtOR (2018, p. 143, figs 1-3, as Planothidium sp. 2) in La Cure River at Foissy, Côte-d'Or department,
Bourgogne-Franche-Comté region, France. Other populations from North America include Canada (LAvoIE et al. 2008, pl. 13, as "Planothidium rostratum" pro parte, including one raphe valve image).

\section{Planothidium brasiliense C.E.Wetzel et S.Blanco sp. nov. (Figs 211-217 LM)}

LM (Figs 211-217): Valves lanceolate to elliptic-lanceolate with convex margins and rostrate apices. Valve dimensions: length 20-28 $\mu \mathrm{m}$, width 7.0-8.0 $\mu \mathrm{m}$. Rapheless valve (Figs 211-214): axial area narrow, linear and slightly expanded in the central area opposite to the cavum. Central area with a unilateral large horseshoe-shaped hyaline area presenting a cavum. Striae weakly radiate throughout the entire valve, $15-17$ in $10 \mu \mathrm{m}$ (mean $=$ 16), measured at the central part of the valve opposite to the cavum. Raphe valve (Figs 215-217): axial area narrow, linear. Central area rectangular, bordered on each side by two to three shortened striae. Raphe branches straight with inconspicuous raphe endings.

Type: BRAZIL. Ribeirão das Ostras, Eldorado, São Paulo. Sample SP-255765 housed at the herbarium of the Instituto de Botânica de São Paulo (SP).

Taxonomic remarks: Planothidium brasiliense is separated from other 'rostrate' species in the "P. rostratum"complex by its larger valves and by its unique areolation pattern. The cavum aperture is wider than other species within the complex. Unfortunately, due the rarity of the species in the samples, SEM observations are lacking.

Planothidium frequentissimum (Lange-Bertalot) Lange-Bertalot in LANGE-BERTALOT 1999 (Figs 251-282, LM; 344-353, SEM)

$\equiv$ Achnanthes lanceolata var. dubia f. minuta Grunow in VAN HeURCK (1882-1885, p. 65); - Achnanthes lanceolata ssp. frequentissima LangeBertalot in Krammer \& LANGE-Bertalot (1991, p. 78); - Achnanthes lanceolata ssp. frequentissima Lange-Bertalot in LANGE-BERTALOT (1993, p. 4); - Achnantheiopsis frequentissima (Lange-Bertalot) Lange-Bertalot in LANGE-Bertalot (1997, p. 207).

LM (Figs 251-282): Valves lanceolate to weakly ellipticlanceolate with convex margins and rostrate, protracted apices (never capitate). Valve dimensions $(n=32)$ : length 7.0-15.5 $\mu \mathrm{m}$, width 4.0-5.5 $\mu \mathrm{m}$. Rapheless valve (Figs 251-266): axial area narrow, straight, linear. Central area with a unilateral small horseshoe-shaped hyaline area presenting a cavum. On the opposite side, striae either not shortened or sometimes slightly shortened, forming hence a small circular area. Striae weakly radiate throughout the entire valve, $14-17$ in $10 \mu \mathrm{m}$, measured at the central part of the valve opposite to the unilateral expansion. Raphe valve (Figs 267-282): axial area narrow, linear, widening near the central area. Central area rectangular to slightly rounded bordered on each side by usually two up to three shortened striae. Raphe branches straight with expanded, drop-like proximal raphe endings. 
Terminal raphe fissures unilaterally deflected. Striae radiate throughout the entire valve, $14-17$ in $10 \mu \mathrm{m}$.

SEM (Figs 344-353): Rapheless valve (Figs 344-348): striae composed externally of three to (usually) four rows of small same-sized round areolae (Figs 344-347). Striae continuing uninterruptedly shortly onto the valve mantle (Fig. 344). Valve surface with shallow, rounded to irregularly shaped depressions along the apical axis, mainly concentrated at the central area (Figs 344, 345, 347). Internally, cavum with a narrow aperture towards the mantle (Fig. 348). Raphe valve (Figs 349-353): striae broader than the virgae, composed of three to four rows of rounded areolae (Fig. 349), not extending onto the mantle. Striae internally sunken between raised virgae (Figs 351, 353). Areolae internally covered by individual hymenes (Fig. 351). Proximal external raphe endings straight terminating in expanded pores (Figs 349, 350, 352). Terminal raphe fissures bent, continuing shortly onto the valve mantle (Figs 349, 352). Internally, central nodule raised, with proximal raphe endings deflected to opposite sides (Fig. 353), terminating inconspicuously. Terminal raphe endings terminating on faint helictoglossae, shortly continuing on the valve mantle (Fig. 353).

Type: BELGIUM. Brussels. Delogne Coll. as Achnanthes lanceolata var. dubia f. minuta Grunow, slide $\mathrm{n}^{\circ} 236$ in Van Heurck Collection, Meise Botanic Garden (BR!).

Remarks: The name 'Achnanthes lanceolata var. dubia Grunow f. minuta' appeared for the first time as a 'nomen nudum' in the set of slides included in the 'Types du Synopsis des Diatomées de Belgique', Série X, p. 69 , slide $\mathrm{n}^{\circ} 236$, from a sample collected in 'Bruxelles (Belgique)' (Fig. 247). The 'Types' included notes and diagnoses provided by Grunow, but in the case of the above-mentioned species, these notes did not bear any additional information apart of the name. In VAN Heurck $(1880,1885)$ only the nominate variety dubia is presented and illustrated while the forma minuta remained somewhat obscure, only appearing in the set of slides provided by VAN HeURCK $(1885$, p. 69). PATRICK \& REIMER (1966, p. 271, pl. 18, figs 13-15, here reproduced in Fig. 248) observed the 'Type' slide $n^{\circ} 236$ and included it under the variety dubia despite clear differences in size depicted on figures 13-15 (corresponding to ' $P$. frequentissimum') and figs 11-12 corresponding to Planothidium dubium (Grunow) Round \& Bukhtiyarova in Round \& BukHtiYARova (1996). The same slide ("Type $\mathrm{n}^{\circ} 236$ ") was also observed by Moss \& CARTER (1982, here reproduced in Fig. 249) when finally, the difference between species with 'cavum' and 'sinus' started to be understood and discerned, a step that revolutionized our understanding of species bearing the name 'Achnanthes rostrata' and 'Achnanthes lanceolata'. MOSS \& CARTER (1982) included Van Heurck's slide 236 as well as the slide BM 26547 from London within the same concept including the whole complex under the name Achnanthes rostrata Østrup, as depicted in their figures 16-25. In this context, LANGE-Bertalot \& Krammer (1989, p. 87) invalidly introduced the varietal epithet 'frequentissima' (as a "Manuskriptnamen") for the species placed under the variety dubia f. minuta (i.e. 'falschen dubiaSippen'). They remarked that the "Sippe aus Brüssel" was cosmopolitan and widespread. For LANGE-BERTALOT \& KRAMMER (1989) Planothidium frequentissimum "regularly occurs in heavily contaminated wastewater biotopes" [free translation]. However, “(...) Because all stages of development in mixed populations invariably differentiate easily, they may or may not be two types or subtypes. However, it is not easy to see that the "false dubia "demes", who are everywhere very often represented, should be synonymous with the (much rarer) A. rostrata 'demes' [free translation]. Populations of $P$. frequentissimum seem to be less often observed than its allied species $P$. victori, which is discussed below.

Planothidium victori Novis, Braidwood et Kilroy in Novis, BRAIDWOOD et KILROY (2012) (Figs 283-343, LM; 354-361, SEM)

= Achnanthes rostrata var. magna F.Straub in StRAUB (1985, p. 139, pl. 10, fig. 142; pl. 11, fig. 142b); - Achnanthes lanceolata var. magna (F.Straub) Lange-Bertalot in Krammer \& LANGE-Bertalot (1991, p. 79, as "Achnanthes lanceolata subsp. frequentissima var. magna", nom. inval.); - Achnanthes lanceolata var. magna (F.Straub) LangeBertalot in LANGe-Bertalot (1993, p. 5, as "Achnanthes lanceolata subsp. frequentissima var. magna", nom. inval.); - Achnantheiopsis frequentissima var. magna (F.Straub) Lange-Bertalot in LANGEBERTALOT (1997, p. 207); = Planothidium frequentissimum var. magnum (F.Straub) Lange-Bertalot in LANGE-BERTALOT (1999, p. 282); $=$ Planothidium caputium J.Zimmermann et R.Jahn in ZIMMERMANN et al. (2014, p. 16, fig. 4.3a-h).

LM (Figs 283-343): Valves lanceolate to weakly elliptic-lanceolate with convex margins and rostrate, protracted apices (never capitate). Valve dimensions: length 4.5-19.5 $\mu \mathrm{m}$, width 4.0-5.5 $\mu \mathrm{m}$. Rapheless valve (Figs 283-297, 307-330): axial area narrow, straight linear. Central area with a unilateral small horseshoe-shaped hyaline area with a cavum. On the opposite side, striae either not shortened or sometimes slightly shortened, forming hence a small circular central area. Striae weakly radiate throughout the entire valve, 14-18 in 10 $\mu \mathrm{m}$, measured at the central part of the valve opposite the unilateral expansion. Raphe valve (Figs 298-306, 331-343): axial area narrow, linear, widening near the central area. Central area rectangular to slightly rounded, usually bordered on each side by two, occasionally three, shortened striae. Raphe branches straight with expanded, drop-like proximal raphe endings. Terminal raphe fissures unilaterally deflected. Striae radiate throughout the entire valve, 14-17 in $10 \mu \mathrm{m}$.

SEM (Figs 354-361): Rapheless valve (Figs 354-357): striae composed externally by three to (usually) four rows of small same-sized round areolae (Figs 354-356). Striae continuing shortly, uninterruptedly onto the valve mantle (Figs 354-356). Valve surface with shallow rounded irregular depressions along the apical axis, 
mainly concentrated at the central and axial area (Figs 354-356). Internally, cavum with a wide aperture towards the mantle (Fig. 357). Raphe valve (Figs 358-361): striae broader than the virgae, composed of four (sometines three) rows of rounded areolae (Figs 358, 360), sometimes with smaller areolae extending onto the mantle (Fig. 358), but usually located on the valve face. Striae internally sunken between raised virgae (Figs 359, 361). Areolae internally covered by individual hymenes (Figs 359, 361). Proximal external raphe endings straight, terminating in expanded pores (Figs 358, 360). Terminal raphe fissures bent, continuing shortly onto the valve mantle (Figs 358, 360). Internally central nodule raised, with proximal raphe endings deflected to opposite sides (Figs 359, 361). Terminal raphe endings ending on faint helictoglossae (Figs 359, 361).

Type: NEW ZEALAND. Canterbury, Styx River (lat. $43^{\circ} 27.80^{\prime}$, long. $172^{\circ} 36.21^{\prime}$ ), periphyton, P.M. Novis and J. Braidwood, 4 November 2009 (CHR618408; cleaned frustules made from culture LCR-S:18:1:1). DNA Bank accession $n^{\circ}$ : JQ610172 (rbcL) and JQ610164 (18S).

Observed material: Switzerland. Lake Loclat, Neuchâtel. Sample P-223 deposited at Musée d'Histoire Naturelle La Chaux-de-Fonds (CH P-223); GERMANY. Borgfeld, Bremen. Wümme River (Bremerhaven BRM, sample E991 at the HustedT diatom collection).

Remarks: STRAUB $(1985,1990)$ investigated several populations of Achnanthes from the Jura Mountains (Switzerland) and found six morphological "Sippen" or groups, which were distinguished according to their cell size and valve outline. These populations were also illustrated by LANGE-BERTALOT \& KRAMMER (1989), Krammer \& LANGe-Bertalot (1991) and LangeBERTALOT (1993) who presented the first micrographs of Straub's populations from Swiss lakes. Among them STRAub (1985) described Achnanthes rostrata var. magna. Its iconotype is reproduced in Fig. 284, among LM images from the same population from Lake Loclat (Switzerland) (Figs 283, 285-290, 292-306). The longer cells show an elongated outline while the smaller ones tend to be elliptic (Figs 295-297).

We consider this taxon to be a synonym of $P$. victori, which has priority at the species level over Straub's variety. We also include here for the sake of comparison, one additional population to show the morphological variability of what we consider $P$. victori: the population illustrated in Figures 307-343 found in the sample from Wümme River (BRM-E991, the lectotype of $P$. rostratoholarcticum) is here chosen to represent the most common phenotype of this group of species in the $P$. frequentissimum-complex. The species differs slightly from $P$. frequentissimum sensu stricto (Figs 251-282) that possesses cells with a rhombic-lanceolate valve outline and a wider axial area. Differences on ultrastructural aspects (SEM) are hardly found (such as areola number per stria, presence of a shallow depression on the valve surface, similar cavum aperture). Achnanthes lanceolata var. magna ( $=P$. victori) seems to be the most common diatom form the "frequentissimum/rostratum-group" found in Europe. Planothidium caputium is currently regarded as a synonym of $P$. victori (JAHN et al. 2017), described on the basis of a teratological clone (Novis et al. 2012). Data derived from rbcL sequencing justify the conspecificity of both taxa (JAHN et al. 2017).

\section{Planothidium straubianum C.E.Wetzel, Van de Vijver} et Ector sp. nov. (Figs 362-385, LM; 440-443, SEM) = Achnanthes rostrata Østrup var. minor (Schulz) F.Straub sensu Straub (1985, p. 139); - "Achnanthes rostrata type allongé-elliptique" (type morphologique ' $r 3$ ') in Straub (1985, pl. 4, fig. 59; pl. 6, figs 77-82; pl. 7, figs 92-94).

LM (Figs 362-385): Valves elliptic-lanceolate with slightly parallel margins and round, obtuse ends. Valve dimensions: length 6.0-14.0 $\mu \mathrm{m}$, width 4.0-5.5 $\mu \mathrm{m}$. Rapheless valve (Figs 362-373, 381-383): axial area narrow, straight linear occasionally slightly expanded (Fig. 368). Central area showing a unilateral small and narrow horseshoe-shaped hyaline area with a cavum. Striae weakly radiate throughout the entire valve, $14-18$ in 10 $\mu \mathrm{m}$, measured at the central part of the valve opposite the unilateral expansion. Raphe valve (Figs 374-380, 384, 385): axial area narrow, widening near the central area. Central area transapically elliptic, bordered on each side (asymmetrically) by one to two shortened striae. Raphe branches straight with expanded, drop-like proximal raphe endings. Terminal raphe fissures unilaterally deflected. Striae radiate throughout the entire valve.

SEM (Figs 440-443): Rapheless valve (Figs 440, 441, 443): striae composed externally of four to five rows of small same-sized round areolae arranged in quincunx (Fig. 440). Striae continuing shortly without interrupted onto the valve mantle (Fig. 440). Valve surface with shallow, rounded, irregular depressions along the apical axis, mainly concentrated at the central area (Fig. 440). Internally, cavum with a narrow aperture opening towards the mantle (Figs 441, 443). Raphe valve (Fig. 442): striae broader than the virgae, composed of three to four rows of rounded areolae (Fig. 442), slightly extending onto the mantle. Proximal external raphe endings straight terminating in expanded pores (Fig. 442). Terminal raphe fissures bent, continuing shortly onto the valve mantle (Fig. 442).

Type: SWITZERLAND. Lac des Taillères, Neuchâtel (Sample P-35). Slide BR-4531 deposited at Meise Botanic Garden (Belgium).

Etymology: We dedicate this species to François Straub (PhycoEco, La Chaux-de-Fonds, Switzerland).

Remarks: KrAMMER \& LANGE-BERTALOT (1991) originally placed this taxon within the Achnanthes lanceolata ssp. 
frequentissima complex. KRAMMER \& LANGE-BERTALOT (1991, pl. 44, figs 4-9) illustrated several valves of the two populations ('r2' and ' $r 3$ ') mentioned in STRAUB (1985). The current analysis of the material from Lac des Taillères showed clearly that there is no difference between the two populations, and that they actually form a continuum from small to larger valves, as can be seen in Figures 362-385. A few years prior to that publication, STRAUB (1985) invalidly made a new combination (since no basionym was formally indicated) for Achnanthes lanceolata var. elliptica f. minor Schulz, transferring it into a variety of A. rostrata: Achnanthes rostrata Østrup var. minor (Schulz) F.Straub. ScHulz (1926) illustrated small-celled, rounded valves, clearly belonging to the genus Planothidium, but showing important differences with the illustrations shown in Straub (1985). The rapheless valve, depicted by ScHulz (1926, fig. 42a) shows distinctly punctated striae, as was also shown by Cleve-Euler (1953, fig. 527 å). Straub (1985) on the other hand shows the typical Planothidium-type broad striae without any areolae separately distinguishable. The confusion most likely arose with the publication of CLeve-Euler (1953) in which valves with the morphology as shown by STRAub (1985) were identified as the SchulZ-taxon. Conspecificity between the Schulz-taxon and the population illustrated by STRAUB (1985) is thus doubtful. Unfortunately, there is no indication where the material PAUL SCHULZ used for his publication is kept, making the verification of the type of the SCHULZ-taxon at present impossible. In JAHN et al. (2017), a population from Lake Baikal (B086_3) was illustrated, showing a high morphological similarity to $P$. straubianum. It was identified as $P$. victori based on rbcL and $18 \mathrm{~S}$ molecular markers grouping together with several strains, including the holotype of the latter species. However, as can be seen from their figure 1, the B086_3 strain, does actually not group entirely together with the $P$. victori strains but was added to the group despite a clear separation from it in the diagram. Two other strains grouping in the same large cluster (JAHN et al. 2017, fig. 1) were separated, without any further explanation, as $P$. frequentissimum and a newly described species $P$. naradoense R.Jahn et al. It is therefore likely that strain B086 3 actually belongs to $P$. straubianum and its inclusion in the $P$. victori clade is only based on an incorrect identification.

\section{Planothidium curtistriatum C.E.Wetzel et Ector sp. nov. (Figs 386-414, LM; 444-456, SEM)}

LM (Figs 386-414): Valves elliptic-lanceolate with convex margins. Larger cells lanceolate but smaller cells elliptical-rounded. Valve dimensions: length 5.5-14.5 $\mu \mathrm{m}$, width 3.5-5.5 $\mu \mathrm{m}$. Rapheless valve (Figs 386-400): axial area wide, lanceolate. Central area showing a unilateral small horseshoe-shaped hyaline area with a cavum. Striae short, weakly radiate throughout the entire valve, 11-14 in $10 \mu \mathrm{m}$, measured at the central part of the valve opposite to the unilateral expansion. Raphe valve
(Figs 401-414): axial area narrow with a weakly defined, somewhat squared, central area, bordered on each side by two slightly shortened striae. Raphe branches straight with expanded, drop-like proximal raphe endings.

SEM (Figs 444-456): Rapheless valve (Figs 444-449): striae short, externally composed of three rows of small, round areolae (Figs 444-446). The row in the middle sometimes show smaller areolae (Fig. 446). One areolae (slightly elongated, or merged) is usually present at the valve mantle (Figs 445, 446). Striae mainly restricted to the valve surface. Valve surface with shallow round irregular depressions along the apical axis (Figs 444, 445). Internally, cavum with a very narrow aperture towards the mantle (Figs 447, 448). Striae deeply sunken in the virgae. Internal mantle areolae usually composed by two merged and larger areolae (Fig. 447). Raphe valve (Figs 450-456): striae broader than the virgae (Fig. 450), composed of three to four rows of rounded areolae (Figs 451-454), not reaching the valve mantle. Central striae have a lanceolate shape becoming narrower towards the axial area (Fig. 452). Proximal external raphe endings straight, ending in conspicuous expanded pores (Figs 451-454). Terminal raphe fissures bent, continuing shortly onto the valve mantle pores (Figs 451-454). Proximal raphe ends deflected into opposite directions (Figs 455, 456).

Type: FRANCE. River Beaume at Le Brignon, AuvergneRhône-Alpes region. Slide BR-4532 deposited at Botanic Garden Meise.

Remarks: Planothidium curtistriatum is perhaps the most easily recognizable new species. It shows a large hyaline axial area and characteristic short striae on the rapheless valves. The species has been found commonly in pristine French rivers. We could not find any illustration of the species in the current literature.

Planothidium hinzianum C.E.Wetzel, Van de Vijver et Ector sp. nov. (Figs 415-439, LM; 457-463, SEM)

= Achnanthes lanceolata ssp. frequentissima Lange-Bertalot sensu Krammer \& LANGE-Bertalot (1991, pl. 44, figs 16, 17, 32, 33); Achnanthes lanceolata var. elliptica Cleve sensu ARCHIBALD \& Schomman (1987, figs 16-19) (?)

LM (Figs 415-439): Valves elliptic-lanceolate with clearly convex margins and round, acutely ends. Valve dimensions: length 8.5-16.5 $\mu \mathrm{m}$, width 5.0-6.5 $\mu \mathrm{m}$. Rapheless valve (Figs 415-429): axial area narrow, widening asymmetrically towards the central area. Central area showing a unilateral, more or less horseshoe-shaped hyaline area with a cavum. Striae weakly radiate throughout the entire valve, becoming strongly radiate towards the valve ends, $14-16$ striae in $10 \mu \mathrm{m}$, measured at the central part of the valve opposite to the unilateral expansion. Raphe valve (Figs 430-439): axial area very narrow, almost not widening near the central area. Central area asymmetrical, wedge-shaped, bordered 
on each side by one to two shortened striae whereas on the other side, striae are lacking. Raphe branches straight with expanded, drop-like proximal raphe endings. Terminal raphe fissures unilaterally deflected. Striae radiate throughout the entire valve.

SEM (Figs 457-463): Rapheless valve (Figs 457-461): striae composed externally by one or two (near the axial area) up to four (near the valve mantle) small samesize rounded areolae (Figs 457, 458). Striae abruptly interrupted on the valve face/mantle junction. Mantle areolae grouped in small groups of 7 to 9 areolae (Fig. 459). Valve surface with sharp straight depression lines irregularly occurring on the axial area but also transapically oriented on the virgae (Figs 457, 458). Internally, the cavum has a prominent aperture towards the mantle joining the nearest virgae (Figs 460, 461). Raphe valve (Figs 462, 463): striae only slightly broader than the virgae, composed of three rows of rounded areolae with a short fourth row inserted near the valve margins (Figs 462, 463). Proximal external raphe endings straight terminating in expanded pores (Figs 462, 463). Terminal raphe fissures bent, continuing shortly onto the valve mantle (Figs 462, 463).

Type: GERMANY. Wümme River, Borgfeld (Bremen), epiphyte on Hypnum. Sample E991. Slide 212/73 in Hustedt Collection (BRM!).

Etymology: We dedicate this species to Friedel Hinz (Friedrich-Hustedt-Zentrum für Diatomeenforschung, Bremerhaven, Germany).

Remarks: LANGE-BERTALOT \& KrAmMER (1989, pl. 85 , fig. 22) depicted one rapheless valve from southern Chile that could belong to $P$. hinzianum and identified it as Achnanthes lanceolata sensu latissimo. A few years later, they illustrated another population from the Euphrates River (Syria) and included it in A. lanceolata ssp. frequentissima (KRAMMER \& LANGE-BERTALOT 1991, pl. 44, figs 32, 33). The species was observed in Portugal (Wetzel, pers. obs. in the Rio Tua), Spain (BlanCO et al. 2010, pl. 43, figs 5, 10, 11), France (PeEters \& EстOR 2018, p. 142, figs 1-18, as Planothidium sp. 1) in Ruisseau de Bussy at Laizy, Saône-et-Loire department, Bourgogne-Franche-Comté region, France) and the sub-Antarctic Region where valves with a more or less similar morphology were observed (Van de Vijver, per. obs.). The species can hardly be confused with any other Planothidium species based on the relatively broad, asymmetrical axial area in the rapheless valve and the asymmetrical central area in the raphe valve. The valves shown in ARCHIBALD \& SchoEman (1987) from the Great Usutu River in Swaziland present a similar asymmetrical central area in the raphe valve, a similar valve outline and a relatively enlarged axial area in the rapheless valve. Further analysis of the Swaziland population will be necessary to establish its correct taxonomic position.
Planothidium cavilanceolatum C.E.Wetzel, M.G.Kelly et Van de Vijver sp. nov. (Figs 464-514, LM; 515-521, SEM)

LM (Figs 464-514): Valves strictly lanceolate with weakly convex margins and slightly protracted (in larger valves), broadly rounded ends. Smaller valves ellipticlanceolate to elliptical. Valve dimensions $(n=51)$ : length 13-30 $\mu \mathrm{m}$, width 5.0-7.0 $\mu \mathrm{m}$. Rapheless valve (Figs 464-476, 490-502): axial area narrow, straight, linear only very weakly widening towards the central area. Central area with a small unilateral horseshoe-shaped hyaline area with a cavum. Striae on the opposite side only rarely shortened. Striae almost entirely parallel throughout the entire valve, becoming weakly radiate near the ends, 12-16 in $10 \mu \mathrm{m}$ (measured at the central part of the valve opposite to the unilateral expansion). Raphe valve (Figs 477-489, 503-514): axial area narrow. Central area asymmetrical, rather small bordered by several shortened striae. Raphe branches straight with expanded, drop-like proximal raphe endings.

SEM (Figs 515-521): Rapheless valve (Figs 515, 516, $519,521)$ : striae composed externally of three to four rows of small rounded areolae (Fig. 515). Striae interrupted at the valve face/mantle junction (Fig. 515) with very short striae present on the mantle. Valve surface with shallow rounded irregular depressions along the entire apical axis (Figs 515, 519). Internally, the cavum has a very broad aperture towards the mantle, joining the nearest virgae (Figs 516, 521). Raphe valve (Figs $517,518,520)$ : striae slightly broader than the virgae, composed of four rows of rounded areolae (Figs 517, 520). Proximal external raphe endings straight terminating in expanded pores (Figs 517, 520). Terminal raphe fissures bent, continuing shortly onto the valve mantle (Fig. 517). Internally, proximal raphe endings deflected into opposite directions (Fig. 518). Small helictoglossae present at the valve ends (Fig. 518).

Type: BELGIUM. Flanders, Kleine Beek - Heidebeek, sample APM138-2015/2016. Slide BR-4533 deposited at Meise Botanic Garden (Belgium).

Additional observed material: United Kingdom. Samples from the Poulter River at Elkesley (a tributary of the Idle, and ultimately, the Trent River). Sample BR-4534 deposited at Meise Botanic Garden (Paratype).

Remarks: Planothidium cavilanceolatum is the largest species within the frequentissimum-complex. Its large dimensions are similar to those of $P$. lanceolatum but the latter can be easily separated based on the absence of a cavum. Apart from the samples illustrated here (Belgium and UK) $P$. cavilanceolatum has been also observed in Spain as $P$. frequentissimum (Blanco et al. 2010, pl. 43, figs 1, 2, 19). 


\section{FinAL REMARKS AND CONCLUSIONS}

It is currently well accepted that accurate taxonomic resolution in light microscopy analyses of microalgae is essential to achieve high quality, comparable results in both floristic analyses and biomonitoring studies (BLANCO et al. 2017), and that morphometry-based identification in diatom taxonomy is discouraged to distinguish some of the complexes. As a practical suggestion we provide a summary in Figure 522 of the basic morphometry of the species discussed in the manuscript and highlight some elements to facilitate identification based on light microscopy observations, such as basic and classic valve dimensions (width, length, $\mathrm{L}: \mathrm{W}$ ratio and number of striae in $10 \mu \mathrm{m}$ ). If the morphometry overlaps (and almost always it does), other characters and features that might help using SEM include: 1) the pattern of valve surface smoothness on the rapheless valve that can be divided into two main groups: one showing irregular lines on the axial area and virgae and the second one with the depressions showing 'round' depressions instead; 2) number of areolae per striae on the rapheless valve; 3 ) rapheless valve striae interrupted or not towards valve mantle and consequently the number of areolae on the mantle can be used as discriminant features at the species level in complement to the morphometry.

The recent description of new Planothidium species in several parts of the world (e.g. Novis et al. 2012; VAN DE ViJVER et al. 2013; WetZel et al. 2013, 2014; BĄK \& LANGE-BerTalot 2014; N'GuesSAN et al. 2014; WetZel \& ECTOR 2014a; KuliKovsKiY et al. 2015) redefined our notion of endemism and restricted geographic distribution for several purported cosmopolitan taxa. The better circumsciption of widely used names is the first step in understanding their ecological ranges and world distribution. Many species complexes are still up to be discovered, mainly in tropical regions where studies are still lacking.

Most of the species here illustrated were already illustrated in the most common books for diatom identification (e.g. KRAMMER \& LANGE-BERTALOT 1991; LANGE-BERTALOT et al. 2017). The older names applied to the species here discussed are summarized on the Tables 3 and 4 and might help as a guide concerning the taxonomic shifts here proposed. This paper provides (without a polyphasic approach) tools to move from coarse-grained diatom taxonomy to a more refined taxonomy concerning common Planothidium species in Europe. Although being far from a monograph on the genus Planothidium, the current manuscript unravels in details the taxonomy of two of the most common names (i.e. P. frequentissimum and P. rostratum) that, apart from Planothidium lanceolatum (VAN DE VIJVER et al. 2013), are quite often found in freshwater environments in Europe.

ACKNOWLEDGEMENTS

This study was realized in the framework of the project DIATOMS of the Luxembourg Institute of Science and Technology (LIST). We gratefully acknowledge Denise C. Bicudo (Instituto de Botânica de São Paulo, Brazil), Friedel Hinz (Friedrich-Hustedt-Zentrum für Diatomeenforschung, Bremerhaven, Germany), Martin Kelly (Bowburn Consultancy, Durham, UK), Rémy Marcel (AQUABIO, Cournon d'Auvergne, France), Marina Potapova (The Academy of Natural Sciences, Diatom Herbarium, Philadelphia, PA, USA), Jeanne Rigaut (GREBE, Groupe de Recherche et d'Etudes Biologie et Environnement, Lyon, France), Francois Straub (PhycoEco, La Chaux-de-Fonds, Switzerland) and Frank Véry (DREAL Auvergne-Rhône-Alpes, France) for providing materials. The Vlaamse MilieuMaatschappij (VMM, Belgium) is also thanked for providing some of the analysed samples.

\section{REFERENCES}

AFNOR (2007): Norme NF T90-354 Décembre 2007. Qualité de l'eau. Détermination de l'Indice Biologique Diatomées (IBD). - 79 pp., Association Française de Normalisation (AFNOR), La Plaine Saint-Denis.

Álvarez-Blanco, I. \& Blanco, S. (2013): Planothidium galaicum sp. nov. (Bacillariophyta, Achnanthidiaceae), a new diatom species from Galician coast, Spain. - Phytotaxa, 151: 44-52. https://doi.org/10.11646/ phytotaxa.151.1.4

Archibald, R.E.M. \& Schoeman, F.R. (1987): Taxonomic notes on diatoms (Bacillariophyceae) from the Great Usutu River in Swaziland. - South African Journal of Botany 53: 75-92. https://doi.org/10.1016/ S0254-6299(16)31478-8

BĄK, M. \& LANGE-Bertalot, H. (2014): Four small-celled Planothidium species from Central Europe proposed as new to science. - Oceanological and Hydrobiological Studies 43: 346-359. https://doi. org/10.2478/s13545-014-0152-9

Blanco, S.; Cejudo-Figueiras, C.; Álvarez-Blanco, I.; BéCARES, E.; HoffMANN, L. \& Ector, L. (2010): Atlas de las Diatomeas de la Cuenca del Duero / Diatom Atlas of the Duero Basin. - 386 pp., Área de Publicaciones, Universidad de León, León.

Blanco, S.; Borrego-Ramos, M. \& Olenici, A. (2017): Disentangling diatom species complexes: does morphometry suffice? - PeerJ 5: e4159. https://doi. org/10.7717/peerj.4159

BukhtiYarova, L.N. (2017): Planothidium bilensis sp. nov. (Bacillariophyta) from a small pond in Kiev megalopolis (Ukraine). - International Journal on Algae 19: 41-50. https://doi.org/10.1615/InterJAlgae.v19.11.30

Chudaev, D.A. \& Gololobova, M.A. (2016): Diatomovye vodorosli ozera Glubokogo (Moskovskaya oblast) [Diatoms of the Glubokoe lake (Moscow region)]. - 446 pp., Товарищество научных изданий КМК [KMK Scientific Press Ltd.], Москва [Moscow] (in Russian).

Cleve-Euler, A. (1953): Die Diatomeen von Schweden und Finnland. Part III. Monoraphideae, Biraphideae 1. Kongliga Svenska Vetenskaps-Akademiens Handlingar, ser. 4, 4: 1-255.

CocQuYT, C. (1998): Diatoms from the Northern Basin of Lake Tanganyika. - Bibliotheca Diatomologica 39: 1-276.

CoMpère, P. (1991): Book reviews. - Belgian Journal of Botany 124: 235-236.

Cox, E.J. (2006): Achnanthes sensu stricto belongs with genera of the Mastogloiales rather than with other monoraphid diatoms (Bacillariophyta). - European Journal of Phycology 41: 67-81. https://doi.org/10.1080/09670260500491543 
Cox, E.J. (2015): Diatoms (Diatomeae, Bacillariophyceae s.1.). - In: Frey, W. (ed.): Syllabus of Plant Families. A. Engler's Syllabus der Pflanzenfamilien, $13^{\text {th }}$ ed. Part 2/1. Photoautotrophic eukaryotic Algae. Glaucocystophyta, Cryptophyta, Dinophyta/Dinozoa, Haptophyta, Heterokontophyta/Ochrophyta, Chlorarachniophyta/ Cercozoa, Euglenophyta/Euglenozoa, Chlorophyta, Streptophyta p.p. - pp. 64-103, Borntraeger Science Publishers, Stuttgart.

Cox, E.J. \& Williams, D.M. (2000): Systematics of naviculoid diatoms: the interrelationships of some taxa with a stauros. - European Journal of Phycology 35: 273-282. https://doi.org/10.1080/09670260010001735871

EsYReVA, V.I. (1945): Flora vodoroslei r. Volgi ot Rybinska do g. Gorkogo. - Trudy Botanicheskogo Sada Moskovskogo Gosudarstvennogo Universiteta (Travaux du Jardin Botanique de l'Université de Moscou) 82: 10-90 (in Russian).

FABRI, R. \& LECLERCQ, L. (1984): Etude écologique des rivières du nord du massif Ardennais: flore et végétation de diatomées et physico-chimie des eaux. 1. Contexte mésologique. Méthodes. Analyses physico-chimiques. Synthèse taxonomique, écologique et floristique. Iconographie. Bibliographie. - 379 pp., 33 pl., Station Scientifique des Hautes-Fagnes, Robertville.

Gasse, F. (1980): Les diatomées lacustres Plio-Pléistocènes du Gadeb (Éthiopie). Systématique, paléoécologie, biostratigraphie. - Revue Algologique, Mémoire hors-série ${ }^{\circ} 3$ : 1-249.

GenkAL, S.I. \& TRIFONOva, I.S. (2009): Diatomovye vodorosli planktona Ladozhskogo ozera i vodoemov ego basseina [Diatom algae of the plankton of Lake Ladoga and water-bodies of its basin]. - 72 pp., Rybinskii Dom Pechati, Rybinsk (in Russian).

GenKal, S.I.; KulikovskiY, M.S.; Mikheeva, T.M.; KuZnetsova, I.V. \& LuK’yANOVA, E.V. (2013): Diatomovye vodorosli planktona reki Svisloch i ee vodokhranilishch. [Diatoms in plankton of the Svisloch River and its reservoirs]. - 236 pp., Scientific World, Moscow (in Russian).

Gogorev, R.M. \& LANGE, E.K. (2015): Achnanthoid diatoms (Bacillariophyta) of relict Lake Mogilnoye (Kildin Island, Barents Sea). - Novosti Sistematiki Vysshikh i Nizshikh Rastenii 49: 13-31.

Hustedt, F. (1911): Beiträge zur Algenflora von Bremen. IV. Bacillariaceer aus der Wümme. - Abhandlungen herausgegeben vom Naturwissenschaftlichen Verein zu Bremen 20: 257-315.

Hustedt, F. (1930): Bacillariophyta (Diatomeae). - In: PASCHER, A. (ed.): Die Süsswasser-Flora Mitteleuropas. Heft 10. - 466 pp., Verlag von Gustav Fischer, Jena.

Hustedt, F. (1957): Die Diatomeenflora des Flußsystems der Weser im Gebiet der Hansestadt Bremen. Denkschrift über den heutigen ökologischen Zustand der Wasserstraßen im bremischen Staatsgebiet auf Grund der Kieselalgen-Flora mit Beziehung auf die Abwasserverhältnisse. - Abhandlungen herausgegeben vom Naturwissenschaftlichen Verein zu Bremen 34: $181-440$.

Hustedt, F. (1959): Die Kieselalgen Deutschlands, Österreichs und der Schweiz unter Berücksichtigung der übrigen Länder Europas sowie der angrenzenden Meeresgebiete. - In: Rabenhorst, L. (ed.): Kryptogamen Flora von Deutschland, Österreich und der Schweiz, 7 (Teil 2, Lief. 6). - pp. 737-845, figs 1106-1179, Akademische Verlagsgesellschaft m.b.h. Leipzig.
JAHN, R. \& KUSBER, W.-H. (2009): A key to diatom nomenclature. - Diatom Research 24: 101-111. https://doi. org/10.1080/0269249X.2009.9705785

Jahn, R.; Abarca, N.; Gemeinholzer, B.; Mora, D.; SkibBe, O.; Kulikovskiy, M.; Gusev, E.; Kusber, W.-H. \& Zimmermann, J. (2017): Planothidium lanceolatum and Planothidium frequentissimum reinvestigated with molecular methods and morphology: four new species and the taxonomic importance of the sinus and cavum. - Diatom Research 32: 75-107. https://doi.or g/10.1080/0269249X.2017.1312548

Kociolek, J.P.; Balasubramanian, K.; Blanco, S.; Coste, M.; ECTOR, L.; LIU, Y.; KulIKOVSKIY, M.; LUNDHOLM, N.; Ludwig, T.; Potapova, M.; Rimet, F.; Sabbe, K.; SAla, S.; SAR, E.; TAYLOR, J.; VAN DE ViJVer, B.; Wetzel, C.E.; Williams, D.M.; WitKowski, A. \& Witkowski, J. (2018): DiatomBase. - Accessed at $\mathrm{http}: / /$ www.diatombase.org on 2018-10-08

Krammer, K. \& LANGe-Bertalot, H. (1991): Bacillariophyceae. 4. Teil: Achnanthaceae, Kritische Ergänzungen zu Navicula (Lineolatae) und Gomphonema. Gesamtliteraturverzeichnis Teil 1-4. - In: Ettl, H.; GÄrtner, G.; GerlofF, J.; Heynig, H. \& Mollenhauer, D. (eds): Süßwasserflora von Mitteleuropa. Band 2/4. - 433 pp., Gustav Fischer Verlag, Stuttgart - Jena.

Krammer, K. \& Lange-Bertalot, H. (2004): Bacillariophyceae. 4. Teil: Achnanthaceae. Kritische Ergänzungen zu Achnanthes s. 1., Navicula s. str., Gomphonema. Gesamtliteraturverzeichnis Teil 1-4. - In: ETTL, H.; GÄrtner, G.; GerlofF, J.; Heynig, H. \& Mollenhauer, D. (eds): Süßwasserflora von Mitteleuropa. Band 2/4. - 468 pp., Spektrum Akademischer Verlag, Heidelberg.

Kulikovskiy, M.; Lange-Bertalot, H. \& WitKowski, A. (2013): Gliwiczia gen. nov. a new monoraphid diatom genus from Lake Baikal with a description of four species new for science. - Phytotaxa 109: 1-16. http:// dx.doi.org/10.11646/phytotaxa.109.1.1

Kulikovskiy, M.; Lange-Bertalot, H. \& Kuzsnetsova, I.V. (2015): Lake Baikal: Hotspot of Endemic Diatoms II. - Iconographia Diatomologica 26: 1-656.

Lange-Bertalot, H. (1993): 85 Neue Taxa und über 100 weitere neu definierte Taxa ergänzend zur Süßwasserflora von Mitteleuropa Vol. 2/1-4. - Bibliotheca Diatomologica 27: $1-428$.

LANGe-Bertalot, H. (1997): Zur Revision der Gattung Achnanthes sensu lato (Bacillariophyceae): Achnantheiopsis, eine neue Gattung mit dem Typus generis A. lanceolata.Archiv für Protistenkunde 148: 199-208. https://doi. org/10.1016/S0003-9365(97)80045-0

Lange-Bertalot, H. (1999): Neue Kombinationen von Taxa aus Achnanthes Bory (sensu lato). - Iconographia Diatomologica 6: 276-289.

Lange-Bertalot, H. \& Krammer, K. (1989): Achnanthes eine Monographie der Gattung mit Definition der Gattung Cocconeis und Nachträgen zu den Naviculaceae. Bibliotheca Diatomologica 18: 1-393.

Lange-Bertalot, H., Hofmann, G., Werum, M. \& Cantonati, M. (2017): Freshwater benthic diatoms of Central Europe: Over 800 common species used in ecological assessment. English edition with updated taxonomy and added species. - In: Cantonati, M.; Kelly, M.G. \& Lange-Bertalot, H. (eds). - 942 pp., Koeltz Botanical Books, Schmitten-Oberreifenberg.

Lavoie, I.; Hamilton, P.B.; Campeau, S.; Grenier, M. \& Dillon, P.J. (2008): Guide d'identification des diatomées des 
rivières de l'Est du Canada. - 241 pp., Presses de l'Université du Québec, Québec.

Loseva, E.I. (1982): Atlas Pozdnepliocenovykh diatomej Prikamya [Atlas of Late Pliocene diatoms of Prikamye]. - 204 pp., Nauka, Leningrad (in Russian).

Lowe, R.L. \& CoDY, W.R. (2002): Planotidium rostratum (Østrup) Lange-Bertalot (Bacillariophyceae) and related species from North American streams and rivers. - In: Morales, E.A. \& Charles, D.F. (eds): Tenth NAWQA Taxonomy Workshop on Harmonization of Algal Taxonomy June 13-15, 2002. Report No. 05-1F. - pp. 63-87, Patrick Center for Environmental Research, The Academy of Natural Sciences of Philadelphia, Philadelphia.

Majewska, R.; De Stefano, M.; Ector, L.; Bolaños, F.; Frankovich, T.A.; Sullivan, M.J.; Ashworth, M.P. \& VAN DE VIJVER, B. (2017): Two new epizoic Achnanthes species (Bacillariophyta) living on marine turtles from Costa Rica. - Botanica Marina 60: 303-318. https:// doi.org/10.1515/bot-2016-0114

Metzeltin, D.; Lange-Bertalot, H. \& García-RodríGuez, F. (2005): Diatoms of Uruguay. Compared with other taxa from South America and elsewhere. - Iconographia Diatomologica 15: 1-736.

Mills, F.W. (1933): An Index to the Genera and Species of the Diatomaceae and their Synonyms, 1816-1932. Part 2 (A). - pp. 74a-148, Wheldon \& Wesley, Limited, London.

Morales, E.A. (2006): Small Planothidium Round et Bukhtiyarova (Bacillariophyceae) taxa related to $P$. daui (Foged) Lange-Bertalot from the United States. - Diatom Research 21: 325-342. https://doi.org/10.1 080/0269249X.2006.9705673

Moss, M.O. \& CARTER, J.R. (1982): The resurrection of Achnanthes rostrata Østrup. - Bacillaria 5: 157-164.

N'Guessan, K.R.; Wetzel, C.E.; Ector, L.; Coste, M.; Cocquyt, C.; Van de Vijver, B.; Yao, S.S.; OuatTara, A.; Kouamelan, E.P. \& Tison-Rosebery, J. (2014): Planothidium comperei sp. nov. (Bacillariophyta), a new diatom species from Ivory Coast. - Plant Ecology and Evolution 147: 455-462. https://dx.doi.org/10.5091/ plecevo.2014.981

Novis, P.M.; Braidwood, J. \& Kilroy, C. (2012): Small diatoms (Bacillariophyta) in cultures from the Styx River, New Zealand, including descriptions of three new species. - Phytotaxa 64: 11-45. https://dx.doi. org/10.11646/phytotaxa.64.1.3

Østrup, E. (1902): Freshwater diatoms. - In: SchмidT, J. (ed.): Flora of Koh Chang. Contributions to the knowledge of the vegetation in the Gulf of Siam. Part VII. - Botanisk Tidsskrift 25: 28-41.

Patrick, R. \& Reimer, C.W. (1966): The diatoms of the United States exclusive of Alaska and Hawaii. Volume 1. Fragilariaceae, Eunotiaceae, Achnanthaceae, Naviculaceae. - Monographs of the Academy of Natural Sciences of Philadelphia 13: 1-688.

Peeters, V. \& Ector, L. (2018): Atlas des diatomées des cours d'eau du territoire bourguignon. Volume 2: Monoraphidées, Brachyraphidées. - 271 pp. Direction Régionale de l'Environnement, de l'Aménagement et du Logement Bourgogne-Franche-Comté, Dijon. http:// www.bourgogne-franche-comte.developpement-durable.gouv.fr/publications-r2759.html

Potapova, M. (2010): Planothidium rostratum. - In: Diatoms of North America. Retrieved October 08, 2018, from https://diatoms.org/species/planothidium rostratum

Potapova, M.G. (2012): New species and combinations in monoraphid diatoms (family Achnanthidiaceae) from North America. - Diatom Research 27: 29-42. https:// doi.org/10.1080/0269249X.2011.644636

Round, F.E. \& BukHtiYarova, L. (1996): Four new genera based on Achnanthes (Achnanthidium) together with a re-definition of Achnanthidium. - Diatom Research 11: 345-361. https://doi.org/10.1080/0269 249X.1996.9705389

Schulz, P. (1926): Die Kieselalgen der Danziger Bucht mit Einschluss derjenigen aus glazialen und postglazialen Sedimenten. - Botanisches Archiv 13: 149-327.

SILVA, P.C. (comp). (2010): Index Nominum Algarum. Bibliographia Phycologica Universalis. The University and Jepson Herbaria, University of California, Berkeley. - Available online at http://ucjeps.berkeley.edu/INA.html

Simonsen, R. (1987): Atlas and Catalogue of the Diatom Types of Friedrich Hustedt. - Volume 1. Catalogue. pp. 1-525. Volume 2. Plates 1-395. Volume 3. Plates 396-772. - J. Cramer in der Gebrüder Borntraeger Verlagsbuchhandlung, Berlin - Stuttgart.

Straub, F. (1985): Variabilité comparée d'Achnanthes lanceolata (Bréb.) Grun. et d'Achnanthes rostrata Østrup (Bacillariophyceae) dans huit populations naturelles du Jura suisse. I: approche morphologique. - Bulletin de la Société Neuchâteloise des Sciences Naturelles 108: 135-150. https://doi.org/10.5169/seals-89244

Straub, F. (1990): Variabilité comparée d'Achnanthes lanceolata (Bréb.) Grunow. 2 : approche biométrique de quelques races de la sous-espèce frequentissima Lange-Bertalot. - In: RicARD, M. (eds): Ouvrage dédié à la Mémoire du Professeur Henry Germain (1903-1989). - pp. 243-249, Koeltz Scientific books, Koenigstein.

Tofilovska, S.; Wetzel, C.E., Ector, L. \& Levkov, Z. (2014): Observation on Achnanthes Bory sensu stricto (Bacillariophyceae) from subaerial habitats in Macedonia and comparison with the type material of $A$. coarctata (Brébisson ex W. Smith) Grunow, A. coarctata var. sinaensis Hustedt and $A$. intermedia Kützing. - Fottea 14: 15-42. https://doi.org/10.5507/fot.2014.002

Tuji, A. (2014): Algae Aquae Dulcis Japonicae Exsiccatae. Fasc. VI. Nos. 101-120. - 25 pp. National Museum of Nature and Science, Tsukuba.

Turland, N.J.; Wiersema, J.H.; BarRie, F.R.; Greuter, W.; Hawksworth, D.L.; HerendeEn, P.S.; KNAPP, S.; Kusber, W.-H.; Li, D.-Z.; MARHold, K.; MaY, T.W.; McNeill, J.; Monro, A.M.; Prado, J.; Price, M.J. \& SMith, G.F. (eds) (2018): International Code of Nomenclature for algae, fungi, and plants (Shenzhen Code) adopted by the Nineteenth International Botanical Congress Shenzhen, China, July 2017. Regnum Vegetabile 159. - 254 pp., Koeltz Botanical Books, Glashütten. https://doi.org/10.12705/Code.2018

Van de Vijver, B.; Wetzel, C.; Kopalová, K.; Zidarova, R. \& ECTOR, L. (2013): Analysis of the type material of Achnanthidium lanceolatum Brébisson ex Kützing (Bacillariophyta) with the description of two new Planothidium species from the Antarctic Region. Fottea 13: 105-117. https://doi.org/10.5507/fot.2013.010

VAN de ViJver, B., Wetzel, C.E. \& Ector, L. (2018): Analysis of the type material of Planothidium delicatulum (Bacillariophyta) with the description of two new Planothidium species from the sub-Antarctic Region. 
- Fottea 18: 200-211. https://doi.org/10.5507/fot.2018.006

Van Heurck, H. (1880): Synopsis des Diatomées de Belgique. Atlas. - pls 1-30, Ducaju \& Cie, Anvers.

Van Heurck, H. (1885): Synopsis des Diatomées de Belgique. Table Alphabétique (Index). - 120 pp., J.F. Dieltjens, Anvers.

VAn Heurck, H. (1882-1885): Types du Synopsis des Diatomées de Belgique. Séries I-XXII. [slides Nr. 1-550]. [Déterminations, notes et diagnoses par $\mathrm{M}$. A. Grunow] - pp. [1]-[118], Anvers.

Wetzel, C.E. \& Ector, L. (2014a): Taxonomy, distribution and autecology of Planothidium bagualensis sp. nov. (Bacillariophyta) a common monoraphid species from southern Brazilian rivers. - Phytotaxa 156: 201-210. https://dx.doi.org/10.11646/phytotaxa.156.4.2

Wetzel, C.E. \& Ector, L. (2014b): Planothidium lagerheimii comb. nov. (Bacillariophyta, Achnanthales) a forgotten diatom from South America. - Phytotaxa 188: 261267. https://dx.doi.org/10.11646/phytotaxa.188.5.3

Wetzel, C.E.; Van de Vijver, B.; Hoffmann, L. \& Ector, L. (2013): Planothidium incuriatum sp. nov. a widely distributed datom species (Bacillaryophyta) and type analysis of Planothidium biporomum. - Phytotaxa 138: 43-57. http://dx.doi.org/10.11646/phytotaxa.138.1.6

Wetzel, C.E.; Van de Vijver, B.; Kopalová, K.; Hoffmann, L.; Pfister, L. \& ECtor, L. (2014): Type analysis of the South American diatom Achnanthes haynaldii (Bacillariophyta) and description of Planothidium amphibium sp. nov., from aerial and aquatic environments in Oregon (USA). - Plant Ecology and Evolution 147: 439-454. https://dx.doi.org/10.5091/plecevo.2014.1058

Zimmermann, J.; Abarca, N.; EnK, N.; Skibbe, O.; Kusber, W.-H. \& JAHN, R. (2014): Taxonomic reference libraries for environmental barcoding: a best practice example from diatom research. PLoS ONE 9 (9): e108793. https://dx.doi.org/doi:10.1371/journal.pone.0108793 


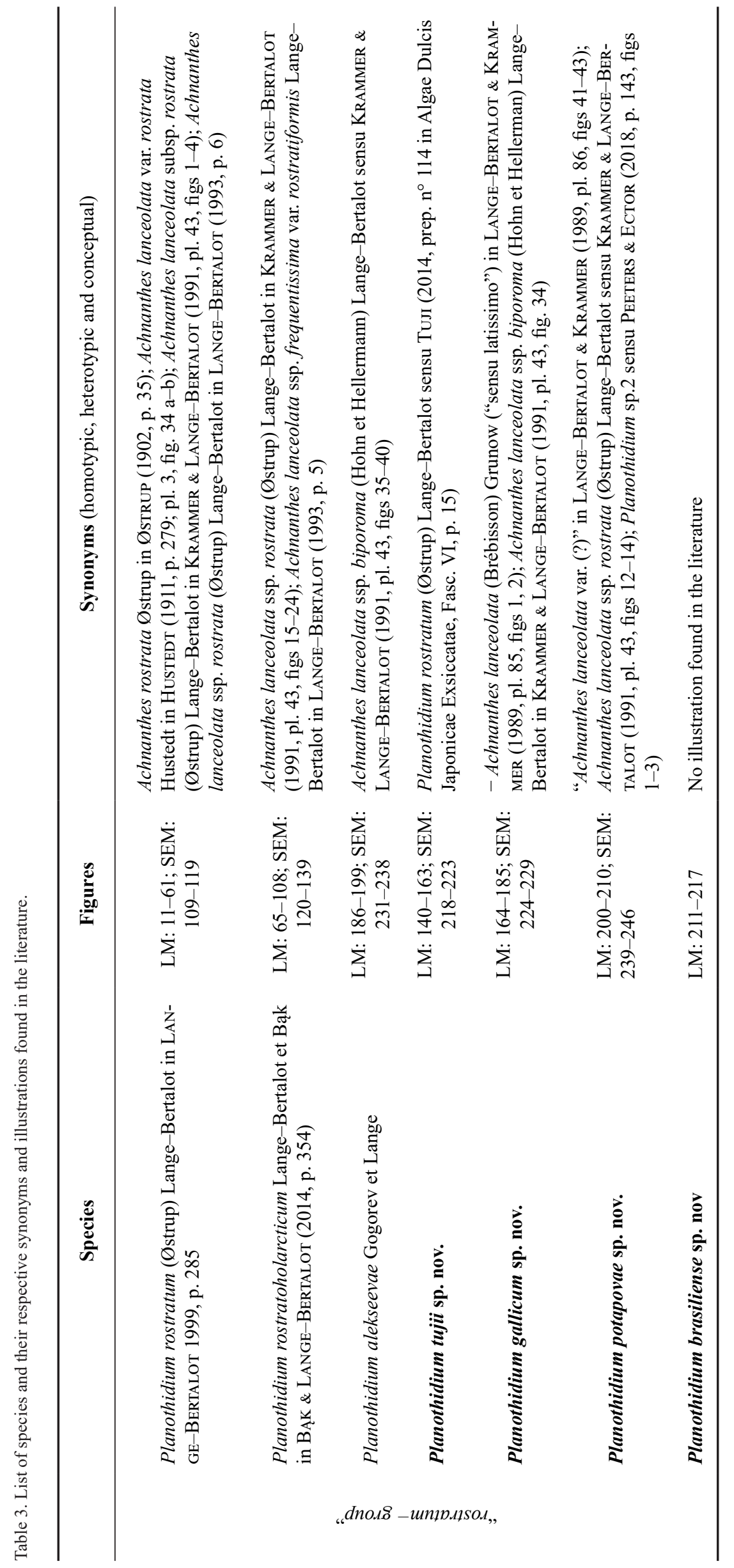




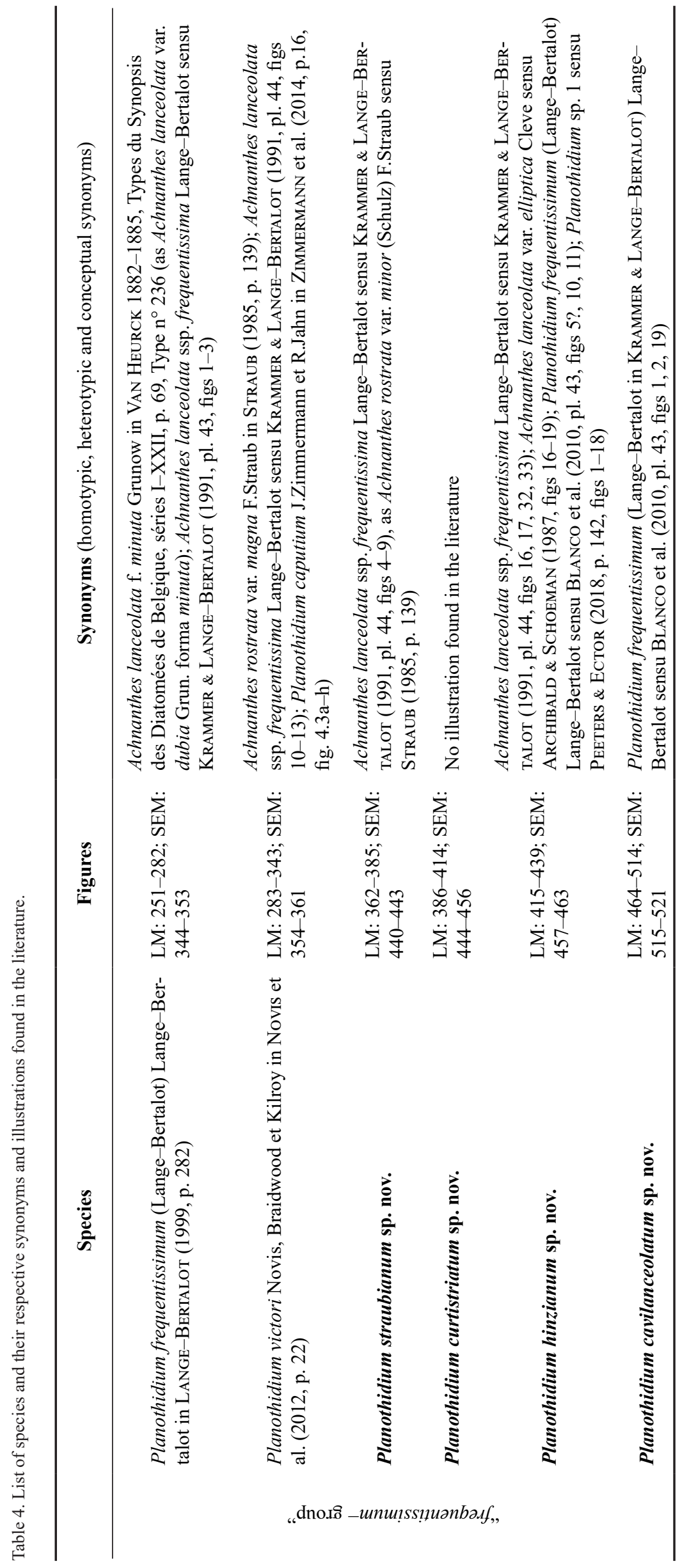




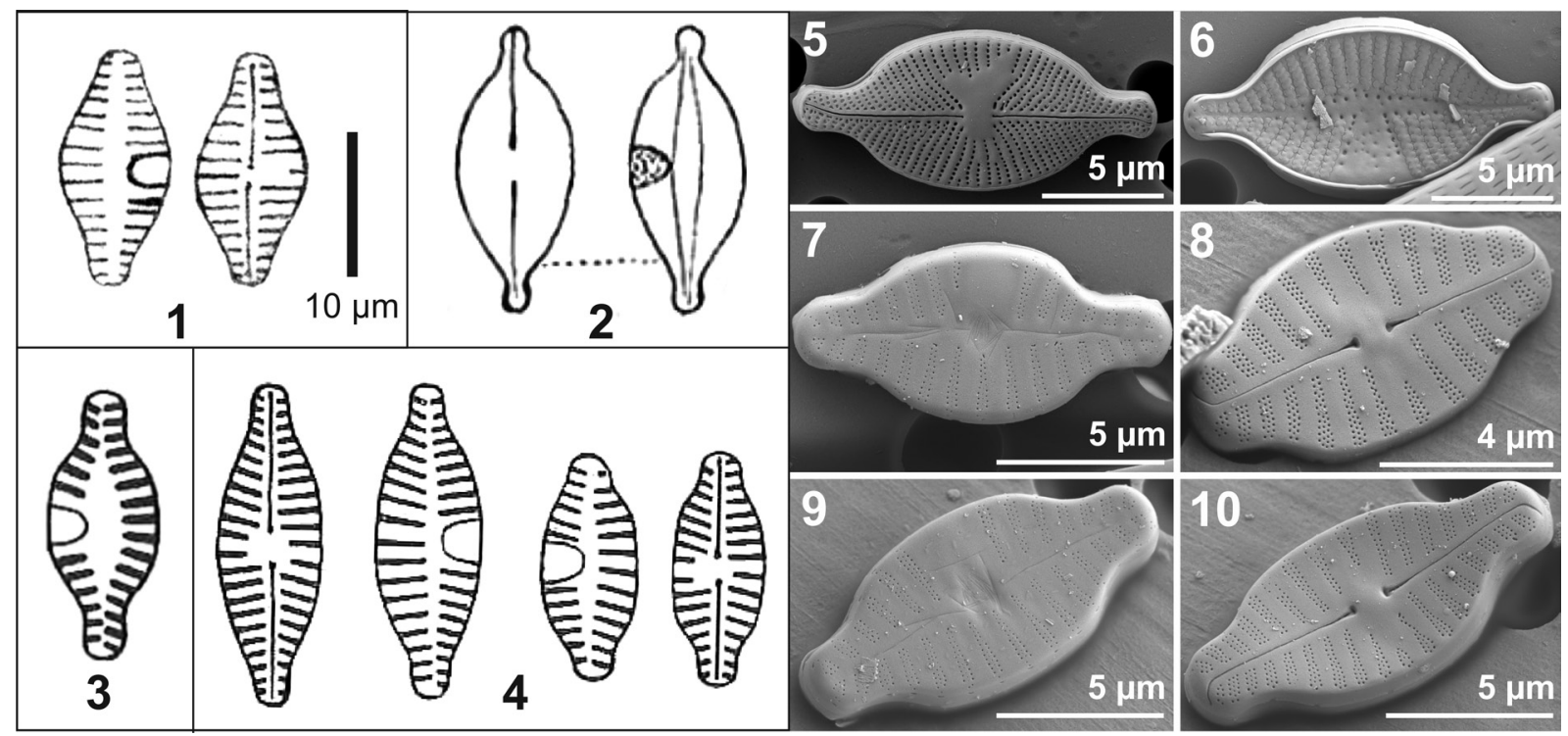

Fig. 1. Achnanthes rostrata (Østrup 1902, p. 35, pl. 1, fig. 11). Fig. 2. Achnanthes lanceolata var. rostrata (Hustedt 1911, pl. 3, fig. 34 a-b) from Wümme River (Germany). Fig. 3. Achnanthes lanceolata var. rostrata (Hustedt 1930, fig. 306b). Fig. 4. Achnanthes lanceolata var. rostrata (HustedT 1959, fig. 863i-m). Figs 5, 6. Skabitschewskia peragalloi (Brun et Héribaud) Kulikovskiy et Lange-Bertalot from the Wümme River (Germany), sample E991 in Hustedt Collection (BRM). Figs 7-10. Planothidium rostratoholarcticum Lange-Bertalot et Bąk in BĄK \& Lange-Bertalot. Figs 5-10. SEM images from specimens from sample E991 (Wümme River, Borgfeld, Germany, in Hustedt Collection). Figs 7-10 agrees with specimens illustrated by SimONSEN $(1987$, pl. 4, figs 6, 7) from the same sample. 


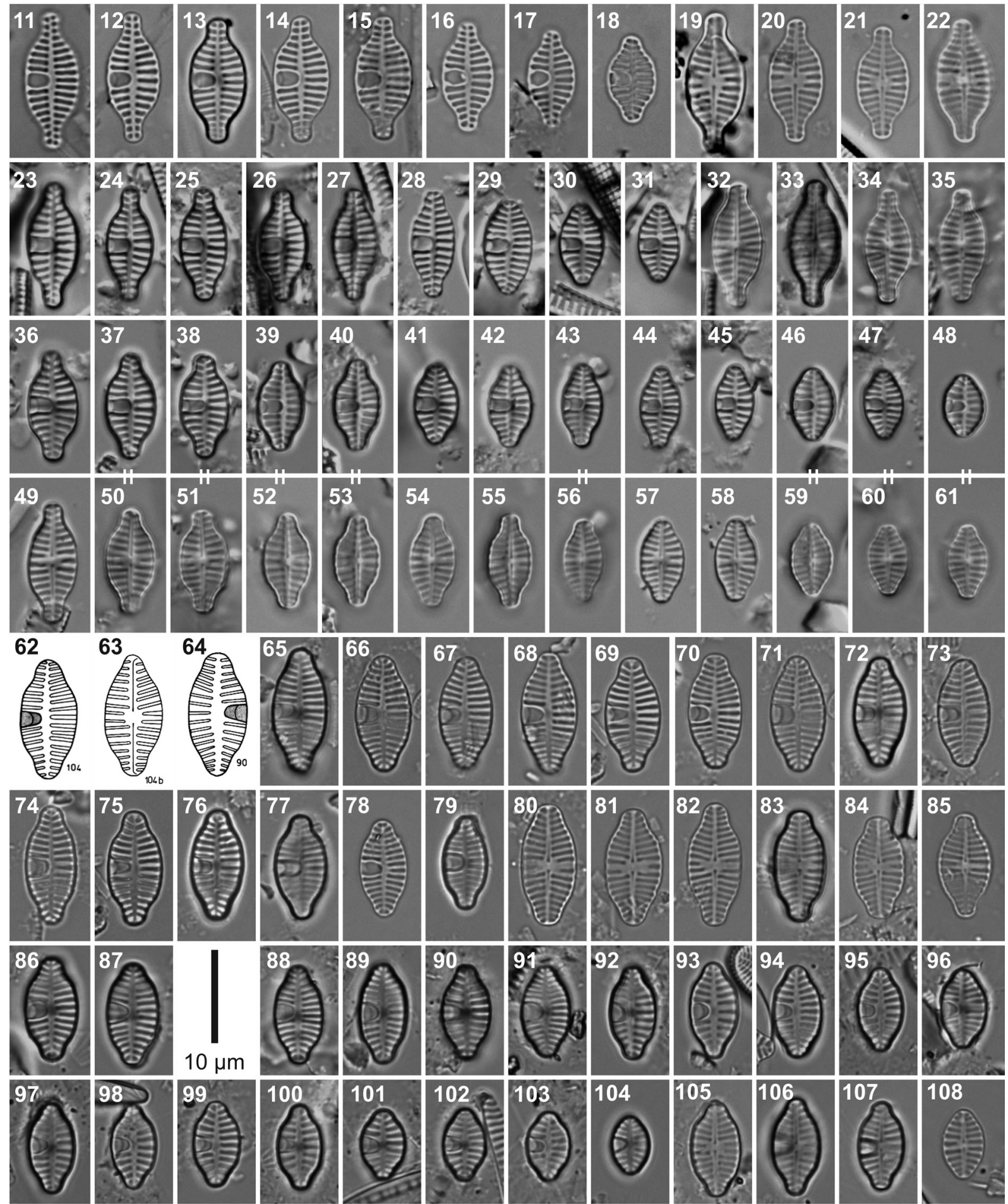

Figs 11-22: Planothidium rostratum (Østrup) Lange-Bertalot. Type material (Klong Sarlakpet, Koh Chang Island, Thailand). Holotype slide 'Va 21. KB Siam F.v.' [Freshwater] 3293. Bot. Mus. Copenhagen (C!). Figs 23-35. Planothidium rostratum from Lake Toba, Balige, Sumatra (Hustedt Coll. AS855). Figs 36-61. Planothidium rostratum from Lake Toba, Meat, Sumatra (Hustedt Coll. AS865). Figs 62-108. Planothidium rostratoholarcticum from European freshwater environments. Figs 62-85. Population from Lac des Taillères, Switzerland (Sample P-35 in StRaub 1985). Figs 62-64 reproduced from Straub (1985, A. rostrata 'type quadrangulaire-rostré). Figs 86-108. Population from the Odra River at Pedrosa del Príncipe, Burgos, Spain. 

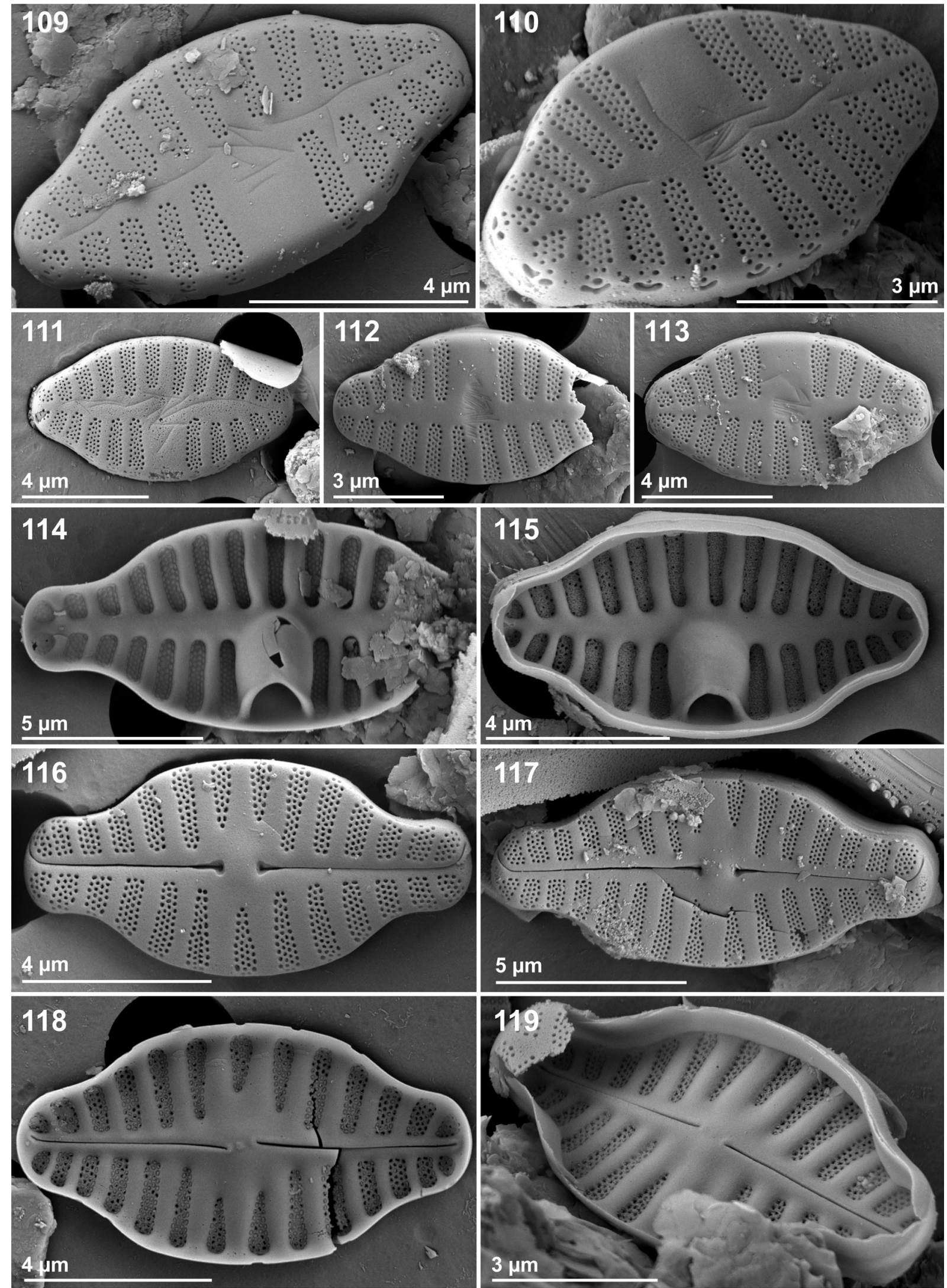

Figs 109-119. Planothidium rostratum (Østrup) Lange-Bertalot. Population from Lake Toba, Balige, Sumatra (Hustedt Coll. AS855). Figs 109-113. External view of rapheless valve. Figs 114, 115. Internal rapheless valves, Figs 116, 117. External view of raphe valve. Figs $118,119$. Internal view of raphe valve. 

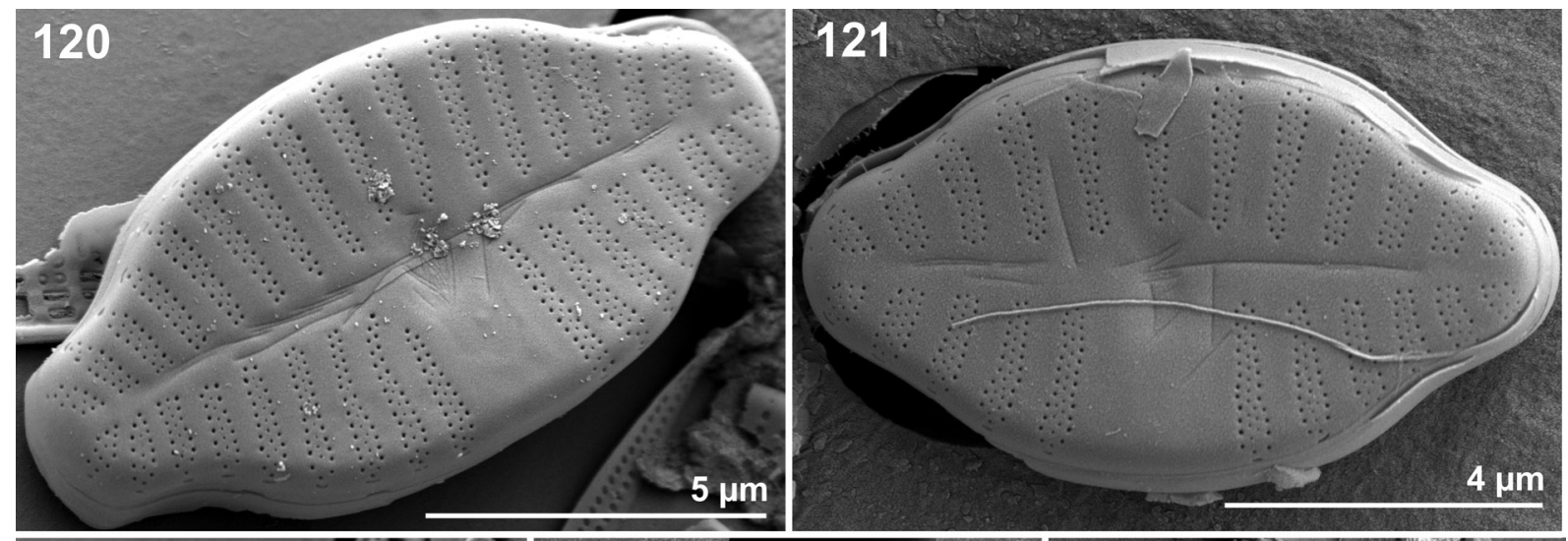
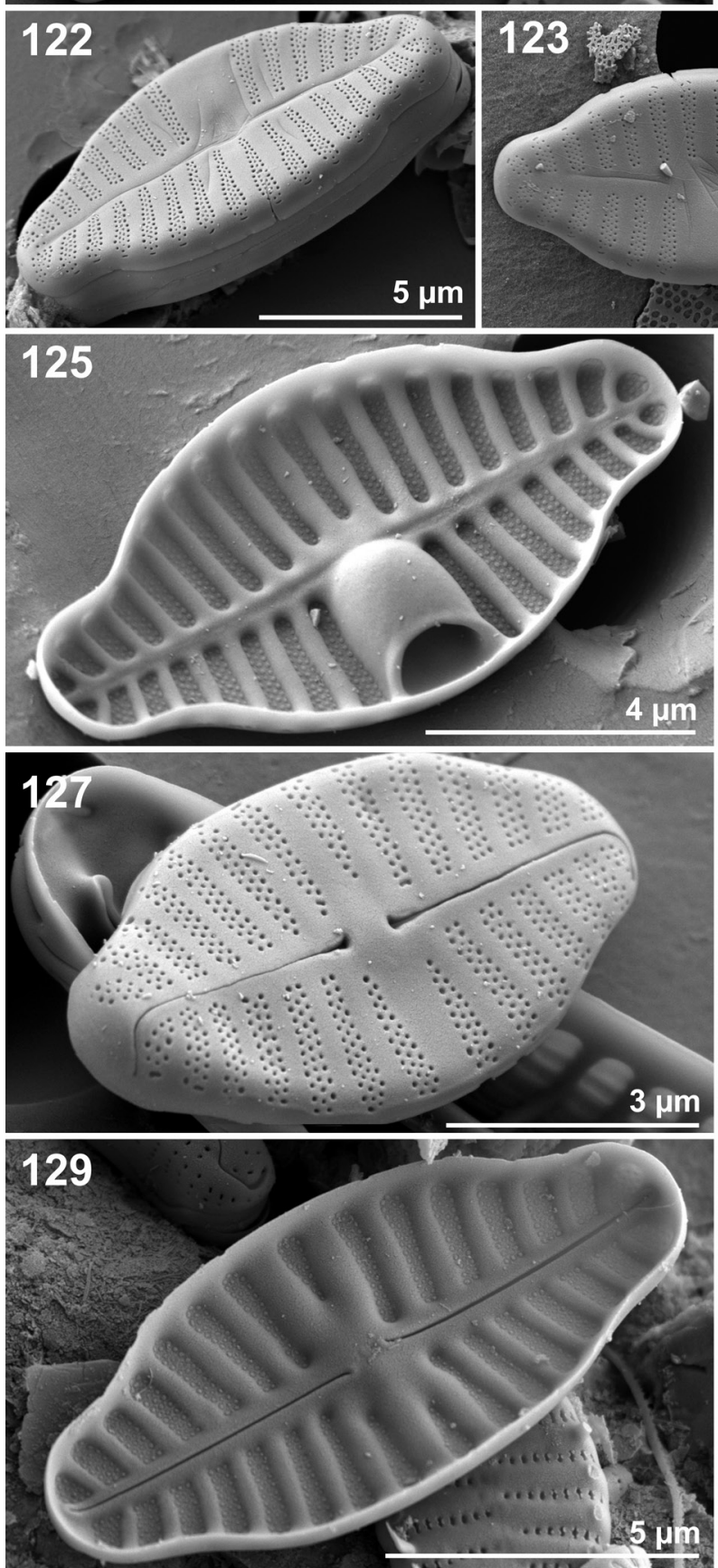

$\min 25$
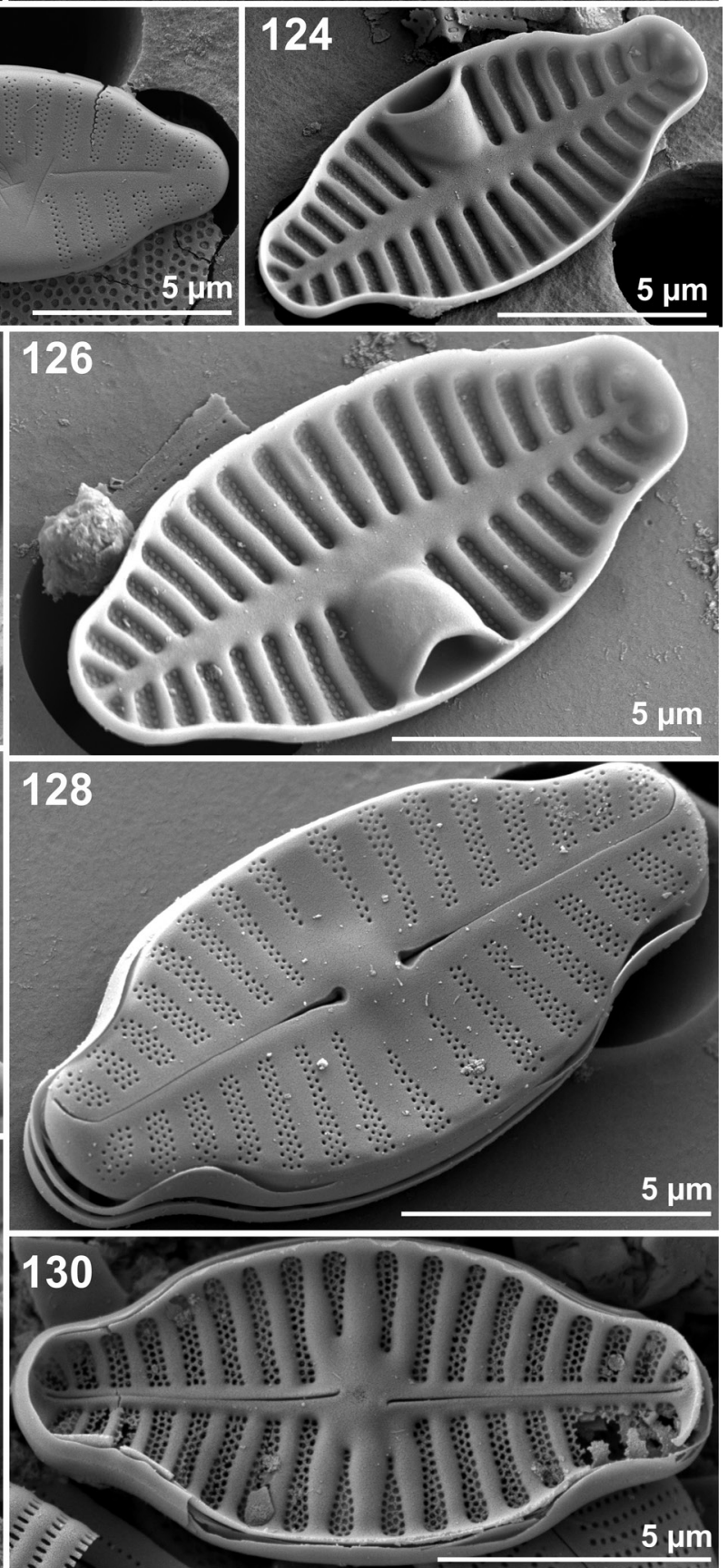

Figs 120-130: Planothidium rostratoholarcticum Lange-Bertalot et Bąk in BĄK \& LANGe-BerTaLot. Population from Lac des Taillères, Switzerland (Sample P-35) corresponding to "type morphologique r6: Achnanthes rostrata 'type quadrangulaire-rostré"” in StRAUB (1985, pl. 6, figs 88, 89, pl. 7, figs 103, 104). Figs 120-123. External views of rapheless valves. Figs 124-126. Internal rapheless valves. Figs 127, 128. External view of raphe valve. Figs 129, 130. Internal view of raphe valve. 

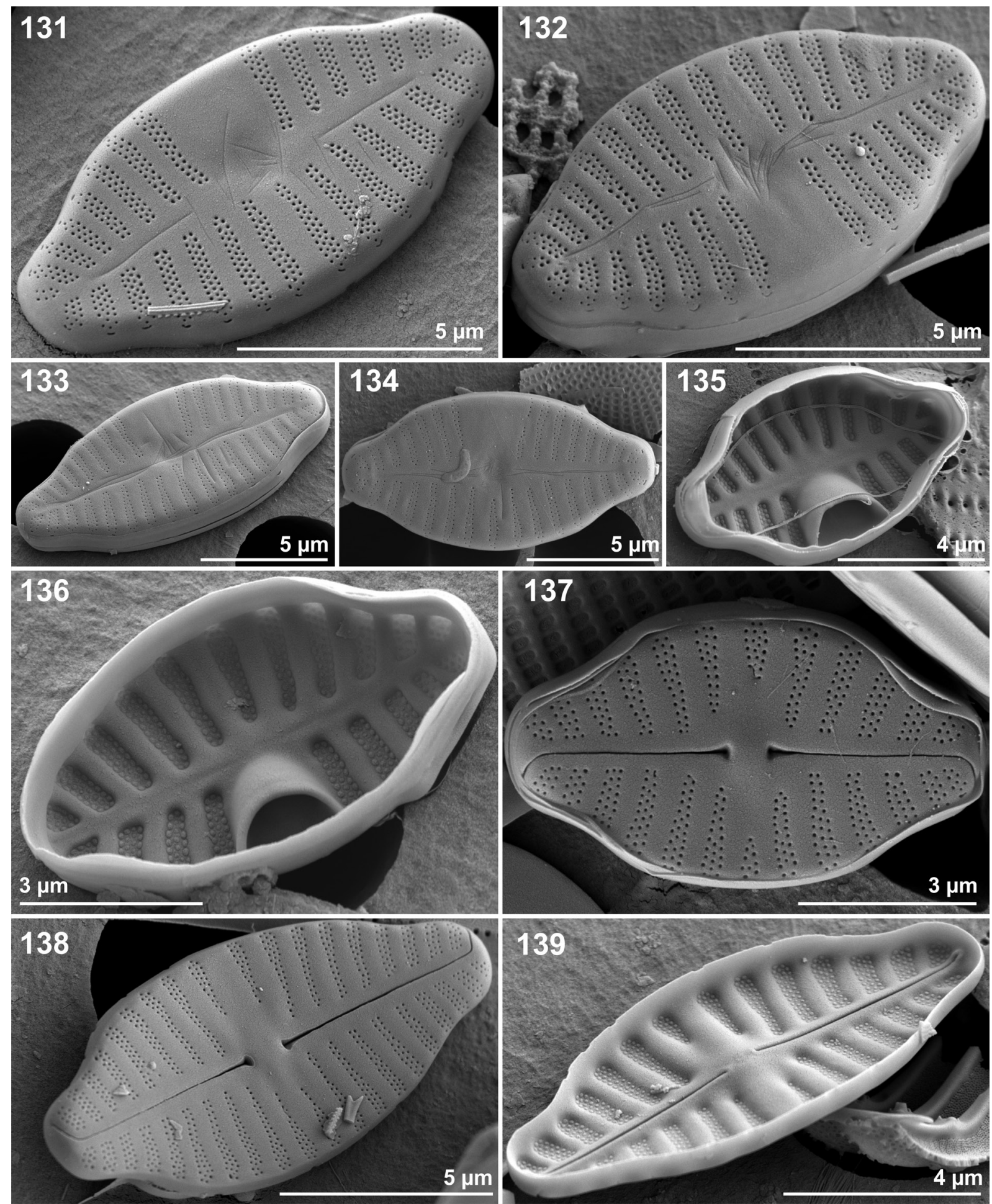

Figs 131-139. Planothidium rostratoholarcticum Lange-Bertalot et Bąk in BĄK \& LANGE-BeRTalot. Population from the Odra River, Pedrosa del Príncipe, Burgos, Spain illustrated in Blanco et al. (2010, pl. 43, figs 33-49). Figs 131-134. External views of rapheless valves. Figs 135, 136. Internal rapheless valve. Figs 137, 138. External view of raphe valve. Fig. 139. Internal view of raphe valve. 


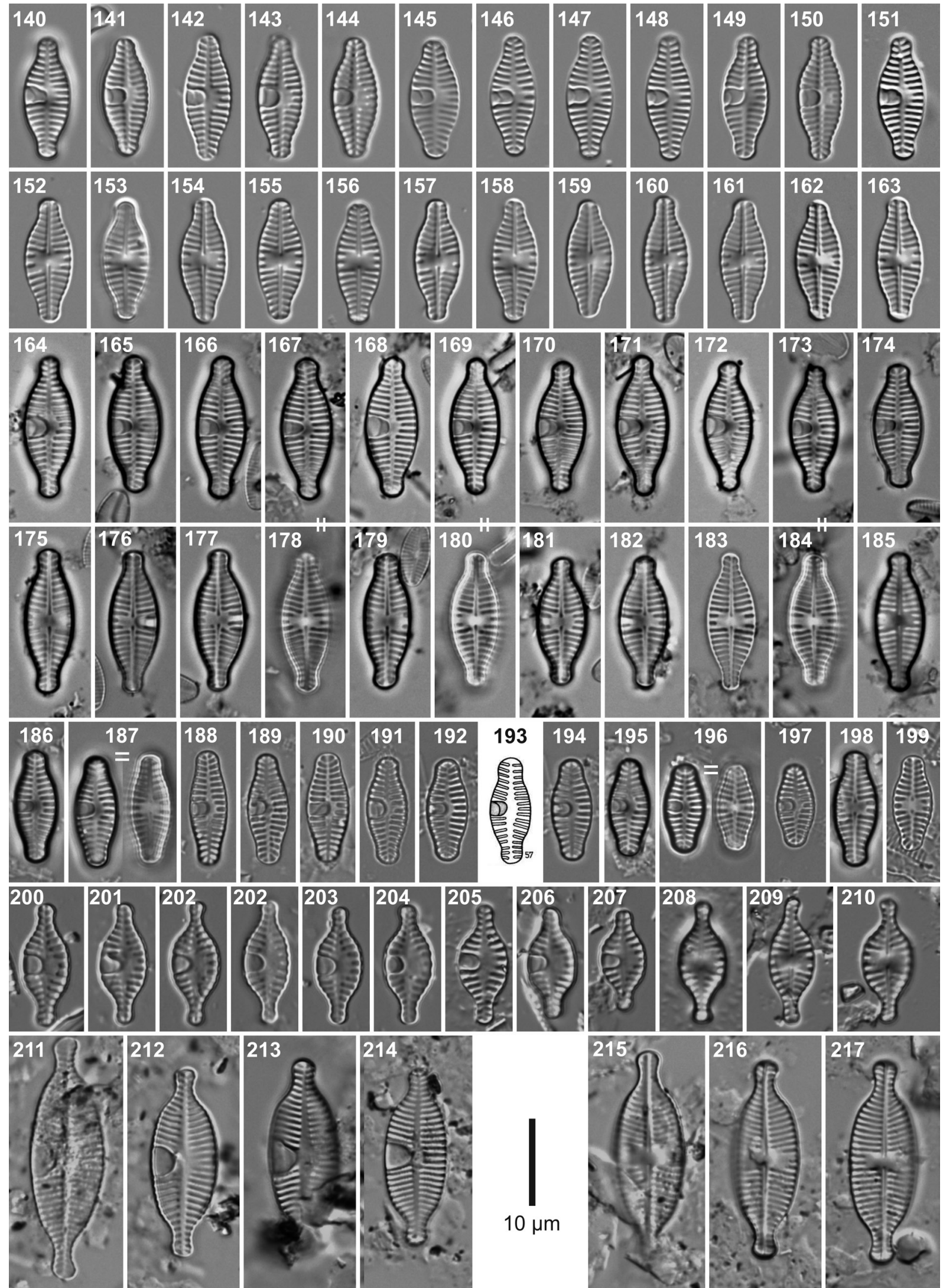

Figs 140-163: Planothidium tujii C.E.Wetzel et Ector sp. nov., Araizawa River, Yuza, Yamagata, Japan. Material TNS-AL-61807 in Algae Aquae Dulcis Japonicae Exsiccatae. Figs 164-185. Planothidium gallicum C.E.Wetzel et Ector sp. nov. Population from the Seine River at Évry-sur-Seine, France. Figs 186-199. Planothidium alekseevae Gogorev et Lange. Sample from Lac des Taillères, Neuchâtel, Switzerland (Sample P-35) corresponding to "type morphologique r5: Achnanthes rostrata 'type capité"' in STRAUB (1985, pl. 4, fig. 57; pl. 6, fig. 87; pl. 7, figs 101, 102). Figs 200-210. Planothidium potapovae C.E. Wetzel et Ector sp. nov. La Boute Vive River at Sainte-Montaine, Centre-Val de Loire region, France. Figs 211-217. Planothidium brasiliense C.E.Wetzel et S.Blanco sp. nov. Ribeirão das Ostras River, Eldorado, Sao Paulo, Brazil (SP-255765). 

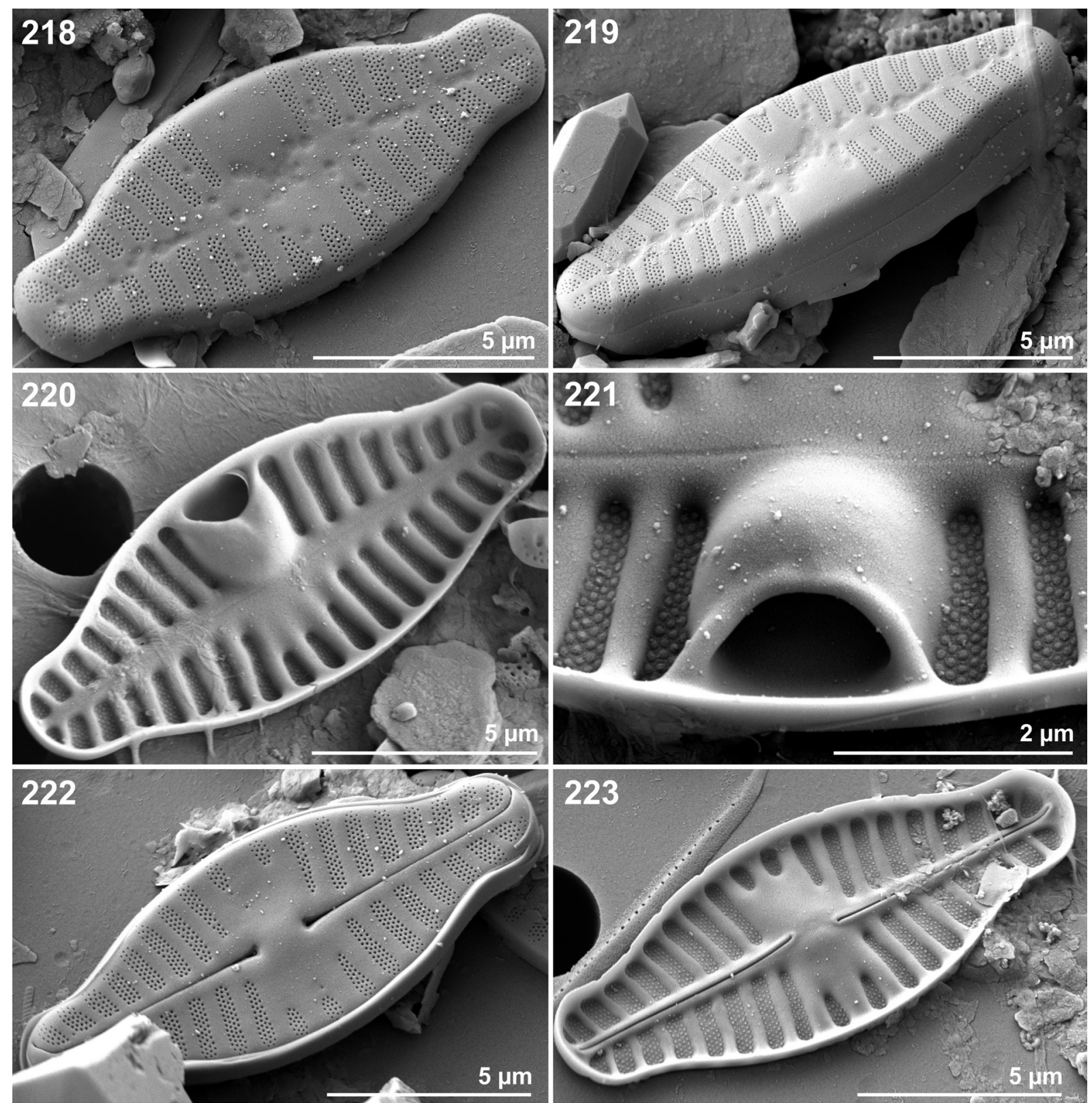

Figs 218-223. Planothidium tujii C.E.Wetzel et Ector sp. nov. Sample from Araizawa River, Yuza, Yamagata, Japan. Holotype material TNSAL-61807. Figs 218, 219. External views of rapheless valves. Figs 220, 221. Internal rapheless valve; detail of cavum aperture. Fig. 222. External view of raphe valve. Fig. 223. Internal view of raphe valve. 

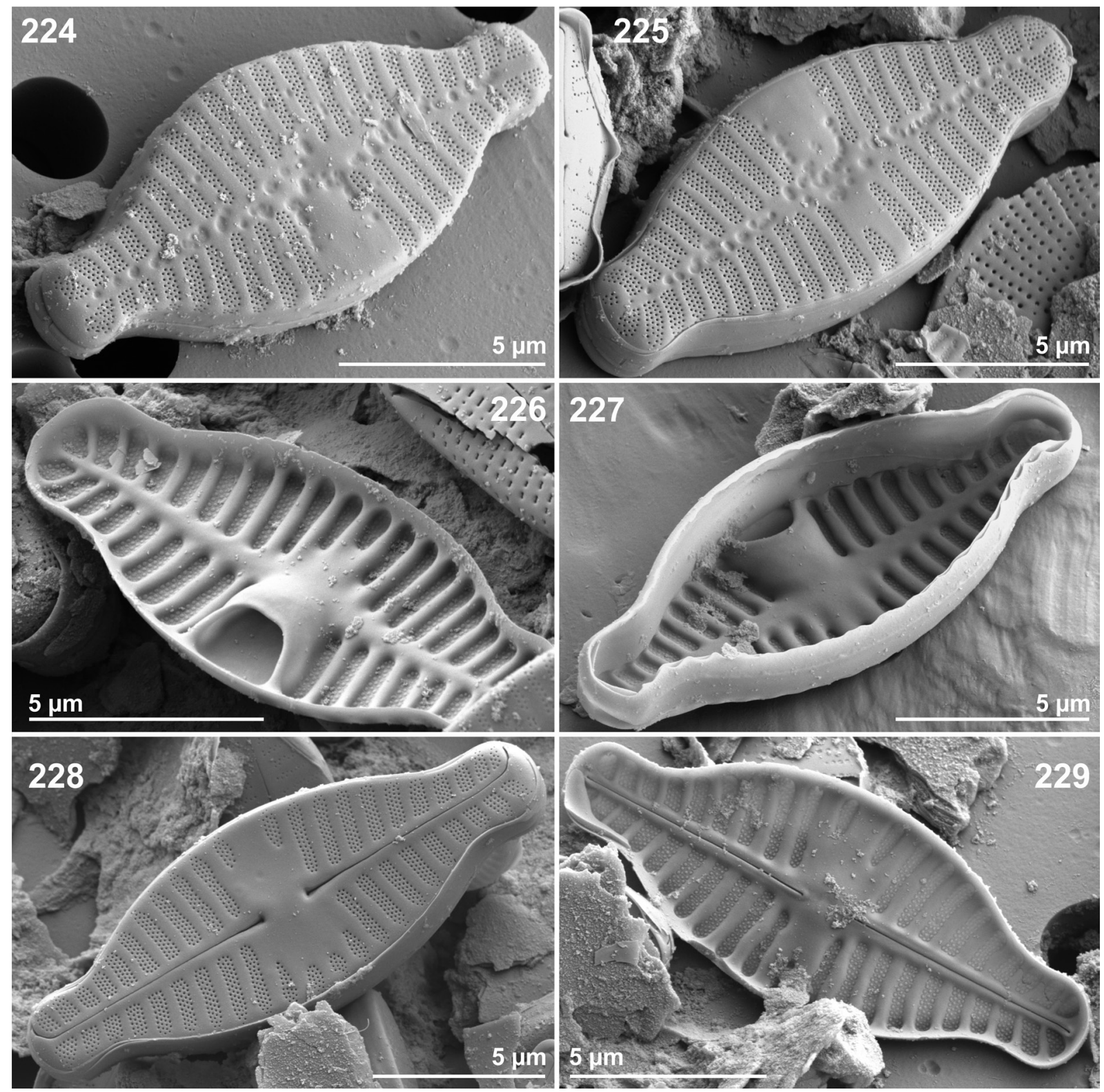

Figs 224-229. Planothidium gallicum C.E.Wetzel et Ector sp. nov. Population from the Seine River at Évry-sur-Seine, France. Figs 224, 225. External views of rapheless valves. Figs 226, 227. Internal rapheless valve. Fig. 228. External view of raphe valve. Fig. 229. Internal view of raphe valve.

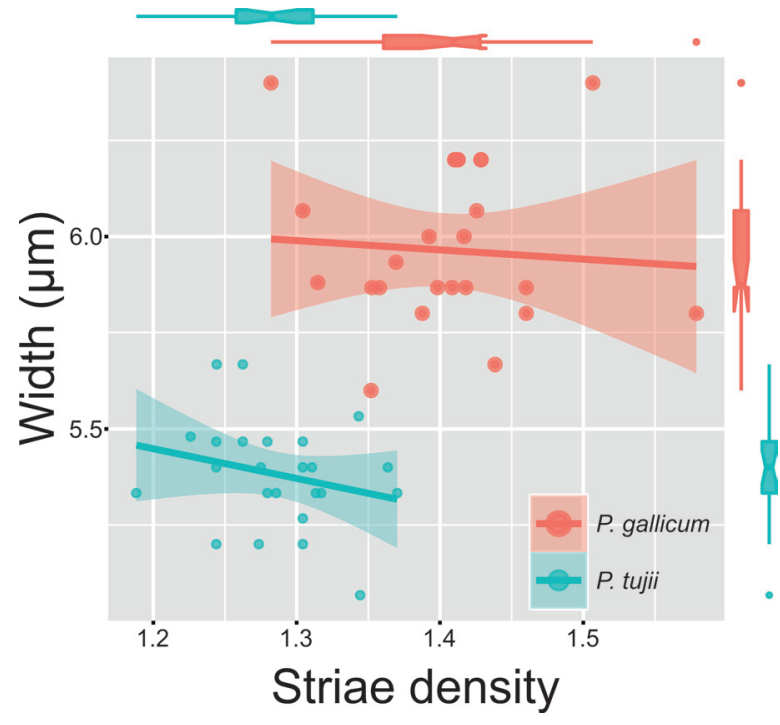

Fig. 230. Scatterplot showing differences in stria density and width of Planothidium gallicum and P. tujii. 

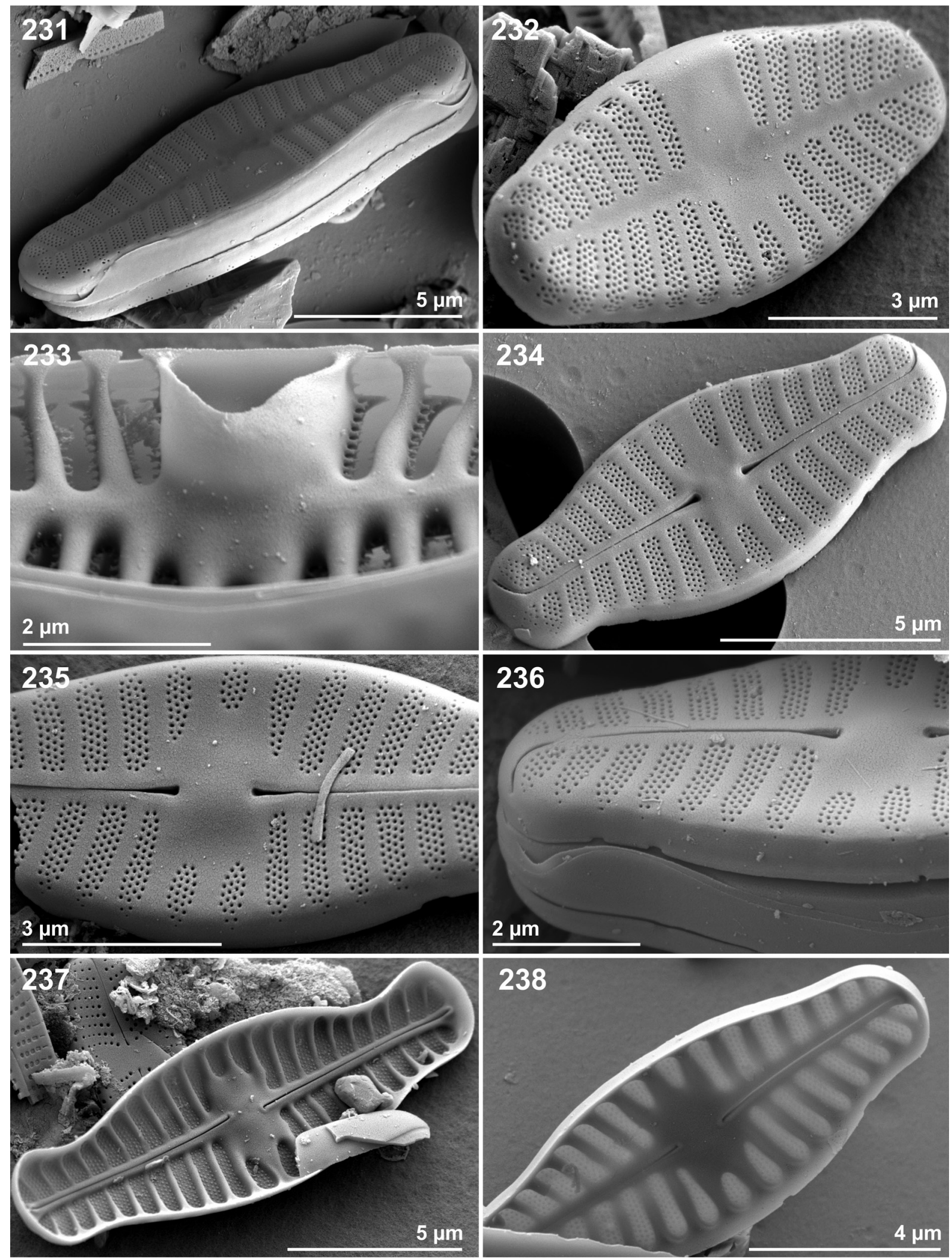

Figs 231-238. Planothidium alekseevae Gogorev et Lange. Sample from Lac des Taillères, Neuchâtel, Switzerland (Sample P-35) corresponding to "type morphologique r5: Achnanthes rostrata "type capité" in STraUB (1985, pl. 6, fig. 87; pl. 7, figs 101, 102). Figs 231, 232. External views of rapheless valves. Fig. 233. Details of eroded cavum; internal rapheless valve. Figs 234-236. External view of raphe valve. Figs 237 , 238. Internal view of raphe valve. 

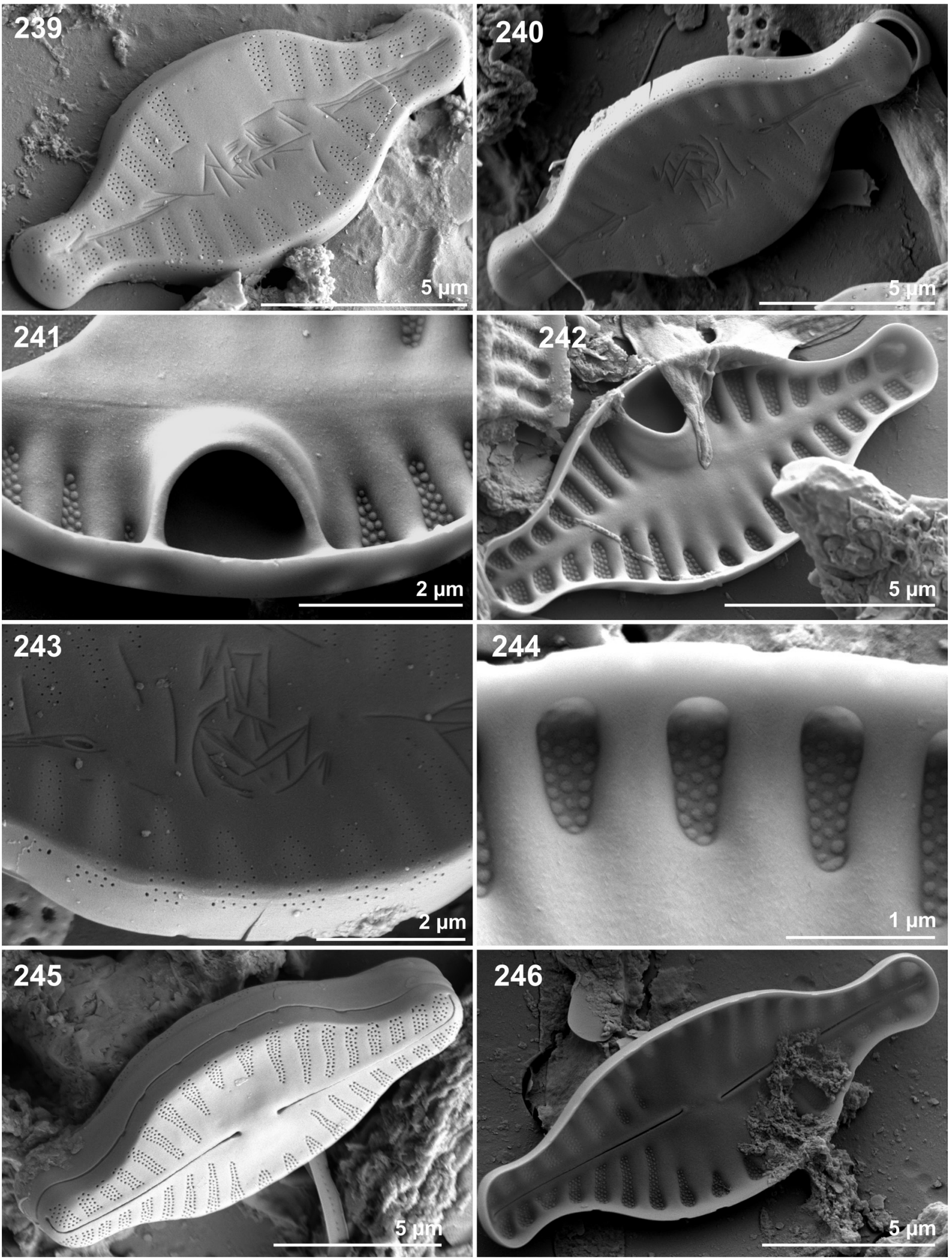

Figs 239-246. Planothidium potapovae C.E. Wetzel et Ector sp. nov. La Boute Vive River at Sainte-Montaine, Centre-Val de Loire region, France. Figs 239, 240. External views of rapheless valves. Figs 241, 242. Details of cavum aperture; internal rapheless valve. Fig. 243. External detail of rapheless valve showing small areolae $n$ the valve mantle and irregular depression lines on the valve surface. Fig. 244. Internal details of rapheless valve showing thick virgae and sunken striae. Fig. 245. External view of raphe valve wit wide central area. Fig. 246. Internal view of raphe valve. 


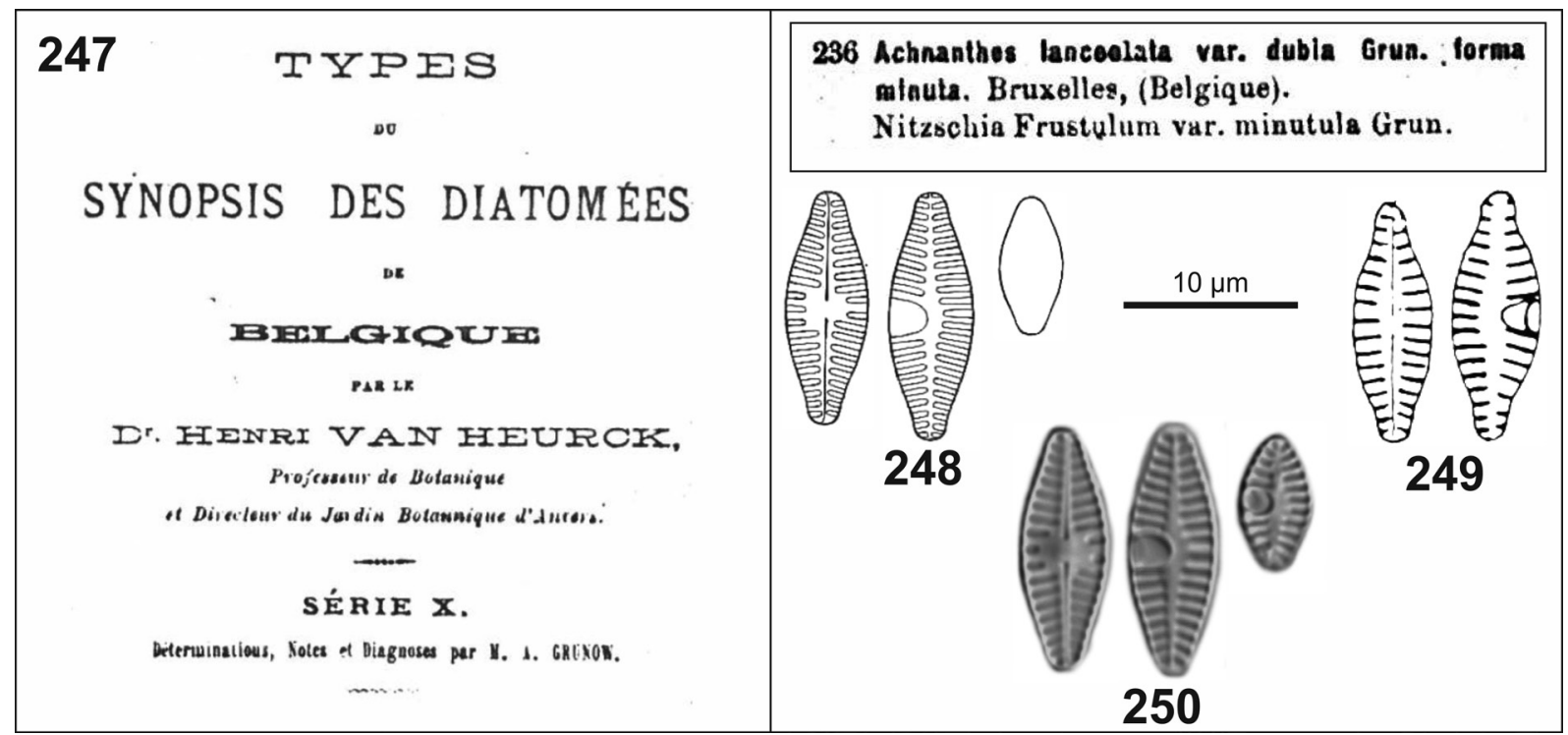

Figs 247-250. Planothidium frequentissimum (Lange-Bertalot) Lange-Bertalot. Fig. 247. Reproduction of the original cover of Types du Synopsis des Diatomées de Belgique by VAN HeURCK (1882-1885, Serie X, corresponding to Achnanthes lanceolata var. dubia forma minuta Type $\mathrm{n}^{\circ}$ 236). Fig. 248. First reproduction by PATRICK \& ReImer (1966, pl. 18, figs 13-15, corresponding to the type $\mathrm{n}^{\circ} 236$ ). Fig. 249. Reproduction of A. lanceolata var. dubia forma minuta by Moss \& CARTER (1982, pl. 2, fig. 20) corresponding to Van Heurck Type n 236 (Slide BM 26547 at British Museum). Fig. 250. LM images of A. lanceolata var. dubia forma minuta from Van Heurck Type $\mathrm{n}^{\circ} 236$. 


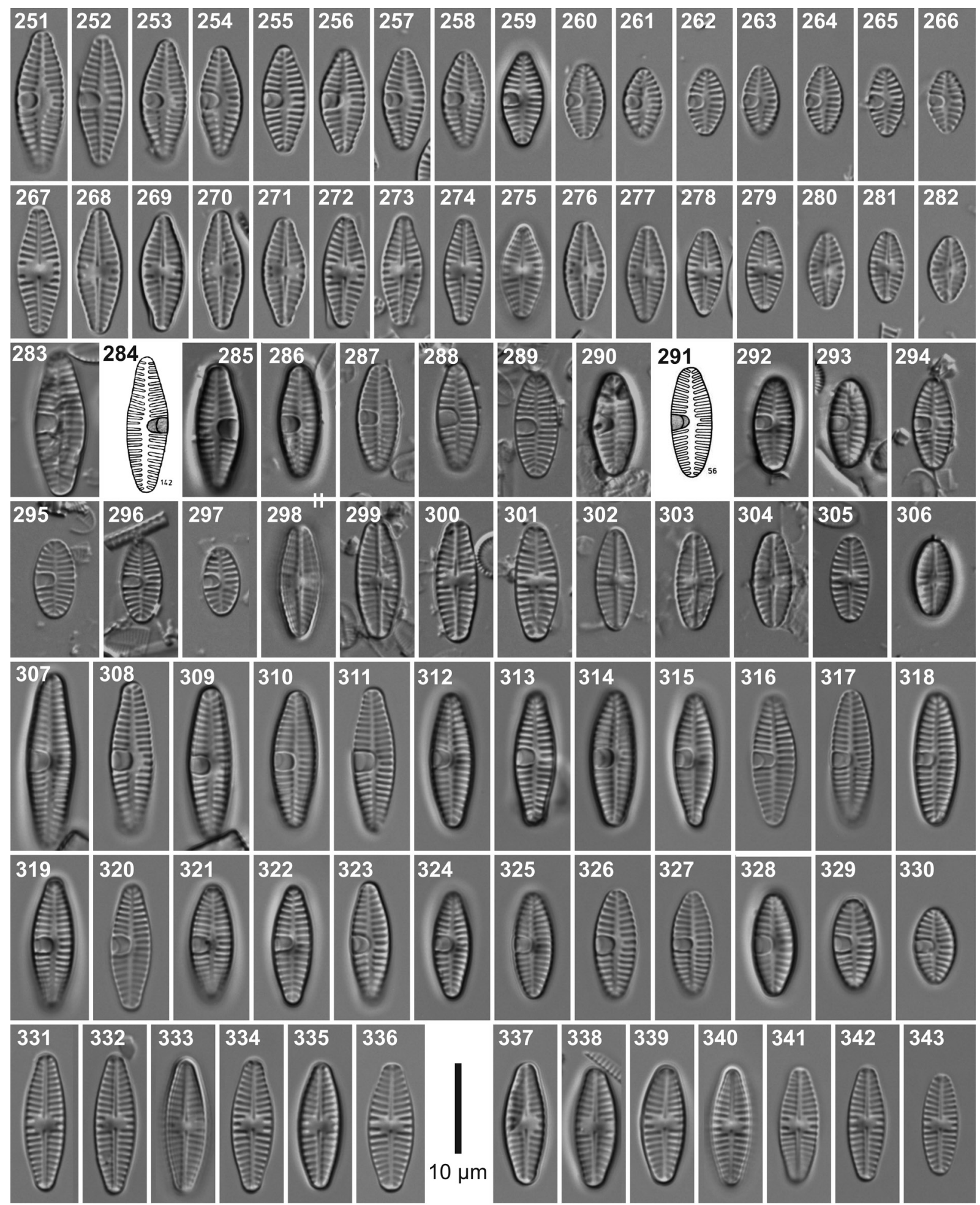

Figs 251-282. Planothidium frequentissimum (Lange-Bertalot) Lange-Bertalot from Bruxelles, Belgium (Type $\mathrm{n}^{\circ} 236$ in Van Heurck Collection). Figs 283-343. Planothidium victori Novis, Braidwood et Kilroy (= Achnanthes rostrata var. magna F.STRAUB). Fig. 284. Reproduction of the 'iconotype' designated by STRAUB (1985, pl. 10, fig. 142) of Achnanthes rostrata var. magna ("type morphologique r4" from Loclat, Neuchâtel). Figs 283-306. Sample from Loclat, Neuchâtel, Switzerland. Sample P-223 in StraUB (1985). Fig. 291. Reproduction of Achnanthes rostrata var. magna ("type morphologique r4" from Lac des Taillères, Neuchâtel) in STRAUB (1985, pl. 4, fig. 56). Figs 307-343. Sample from Wümme River, Borgfeld, Germany (sample E991 in Hustedt collection). 

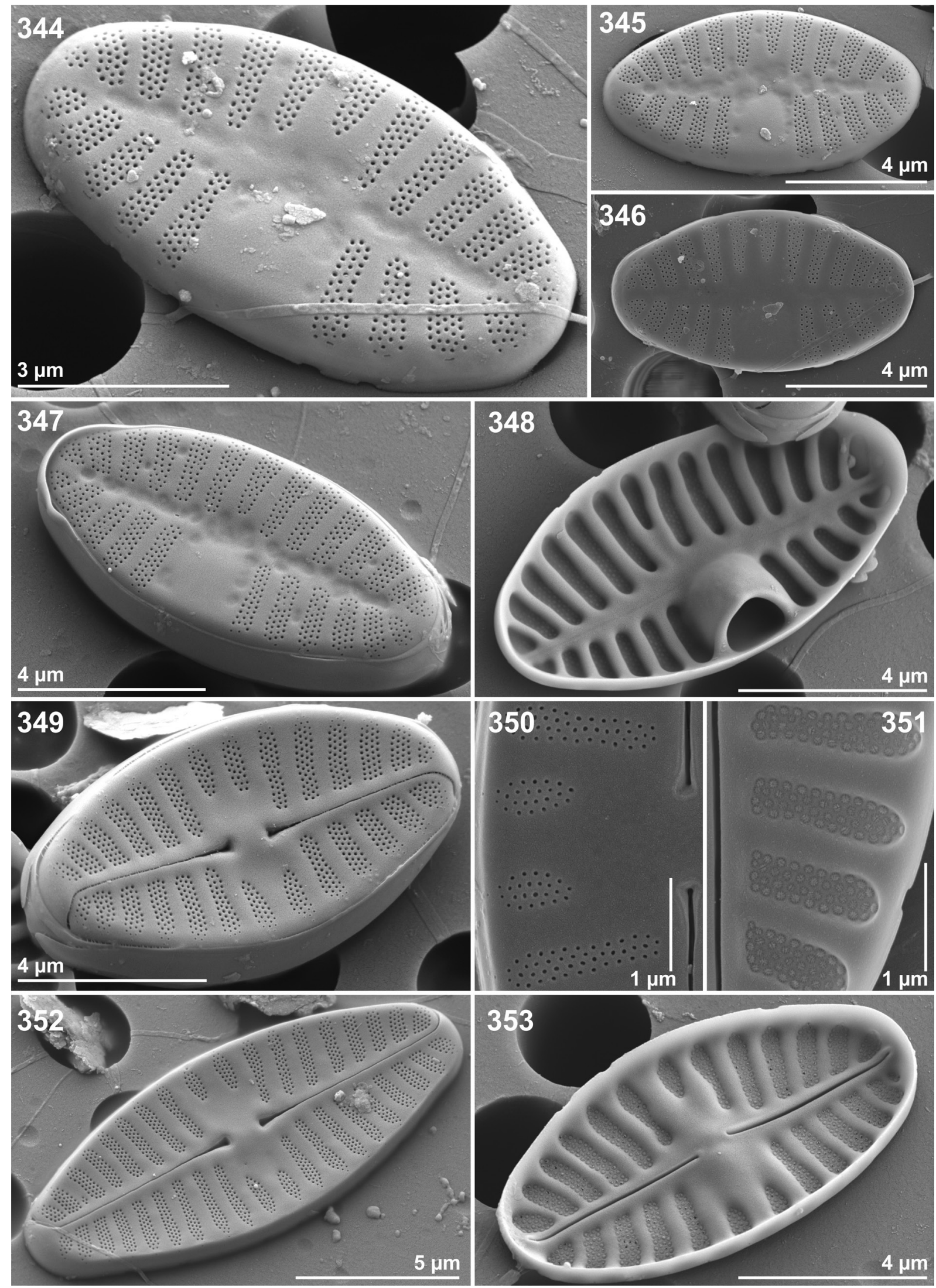

Figs 344-353. Planothidium frequentissimum (Lange-Bertalot) Lange-Bertalot. Bruxelles, Belgium (Synopsis Type $n^{\circ} 236$ in Van Heurck Collection). Figs 344-347. External views of rapheless valves. Fig. 348. Internal rapheless valve. Figs 349, 350, 352. External raphe valve. Fig. 351. Internal detail of raphe valve areolae. Fig. 353. Internal view of raphe valve. 

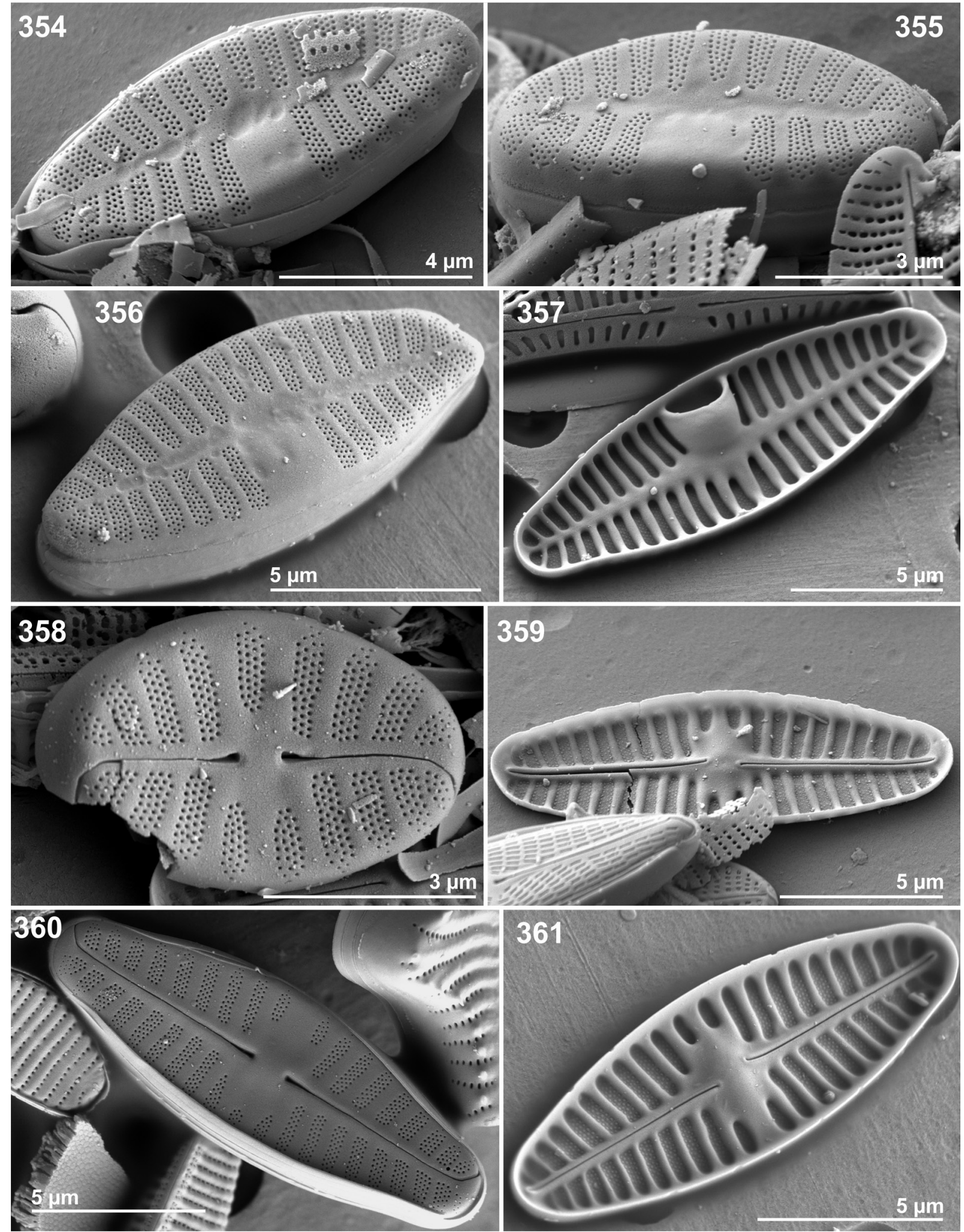

Figs 354-361. Planothidium victori Novis, Braidwood et Kilroy (= Achnanthes rostrata var. magna F.Straub). Figs 354-356, 360. Sample from Loclat, Neuchâtel, Switzerland. Sample P-223 in Straub (1985). Figs 356, 357, 359, 361. Sample E991 in Hustedt Collection, Wümme River, Borgfeld, Germany. Figs 354-356. External views of rapheless valves. Fig. 357. Internal rapheless valve. Figs 358, 359. External raphe valve. Figs 360,361 . Internal raphe valve 


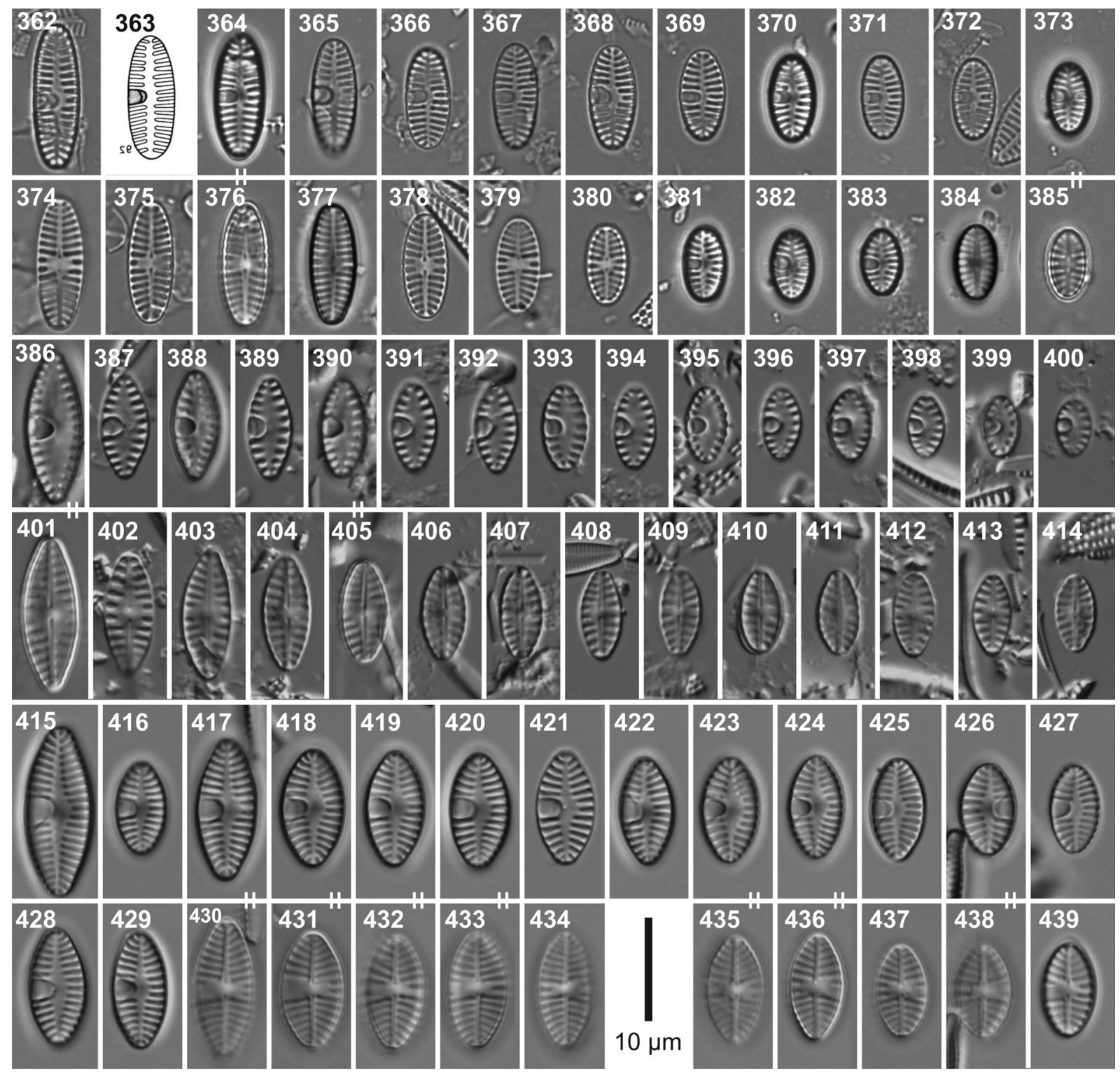

Figs 362-385. Planothidium straubianum C.E.Wetzel, Van de Vijver et Ector sp. nov. Sample from Lac des Taillères, Neuchâtel, Switzerland (Sample P-35) corresponding to "type morphologique ' $\mathrm{r3}$ ' as "Achnanthes rostrata type allongé-elliptique" in StraUB (1985, pl. 4, fig. 59; pl. 6, figs 77-82; pl. 7, figs 92-94). Figs 386-414. Planothidium curtistriatum C.E. Wetzel et Ector sp. nov. Sample from Beaume River at Le Brignon, Auvergne-Rhône-Alpes region (France). Figs 415-439. Planothidium hinzianum C.E. Wetzel, Van de Vijver et Ector sp. nov. Sample E991 in Hustedt Collection, Wümme River, Borgfeld (Germany). 

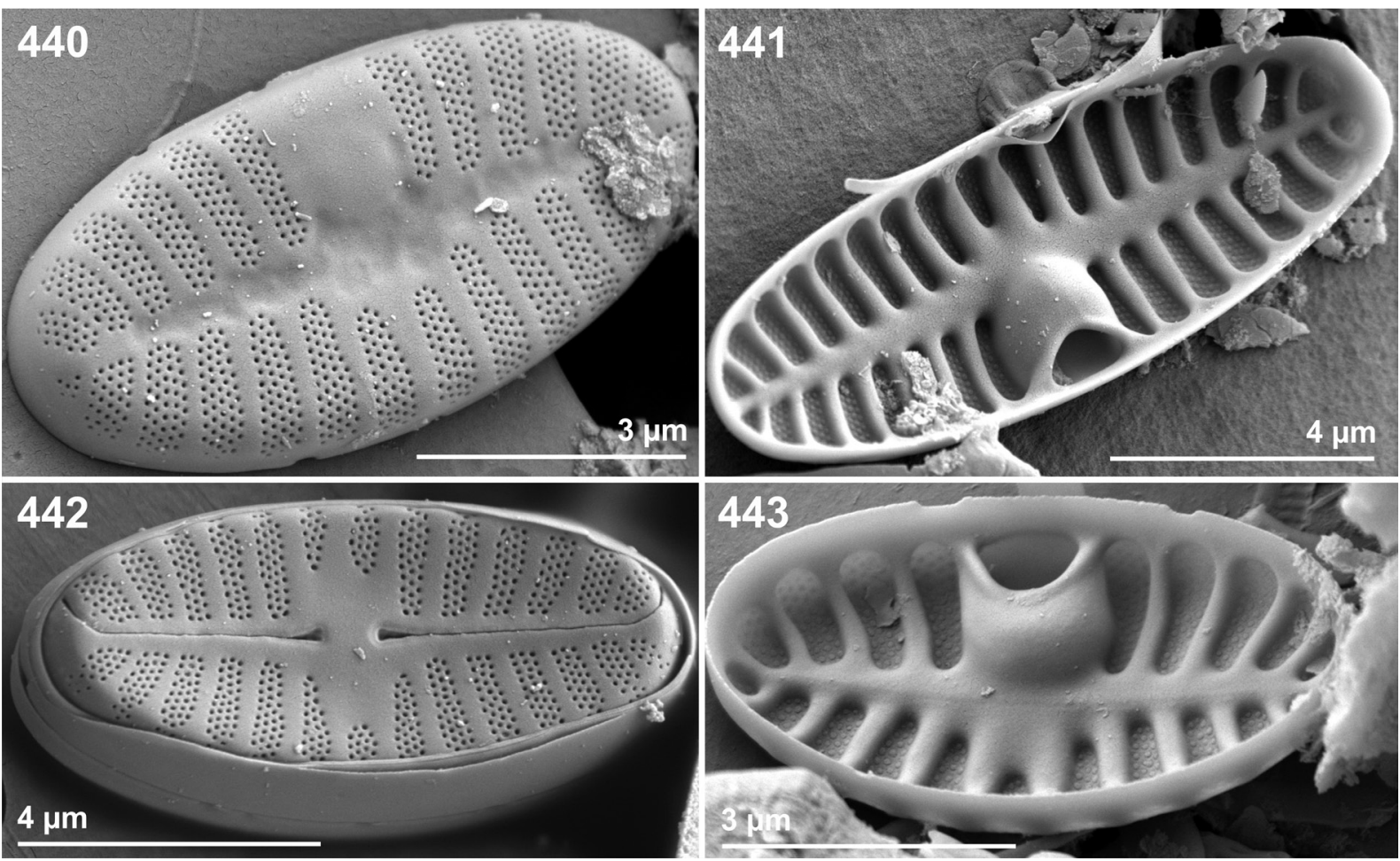

Figs 440-443. Planothidium straubianum C.E.Wetzel, Van de Vijver et Ector sp. nov. Sample from Lac des Taillères, Neuchâtel, Switzerland. Figs 440, 441, 443. External and internal valves view of rapheless valves. Fig. 442. External view of raphe valve. 


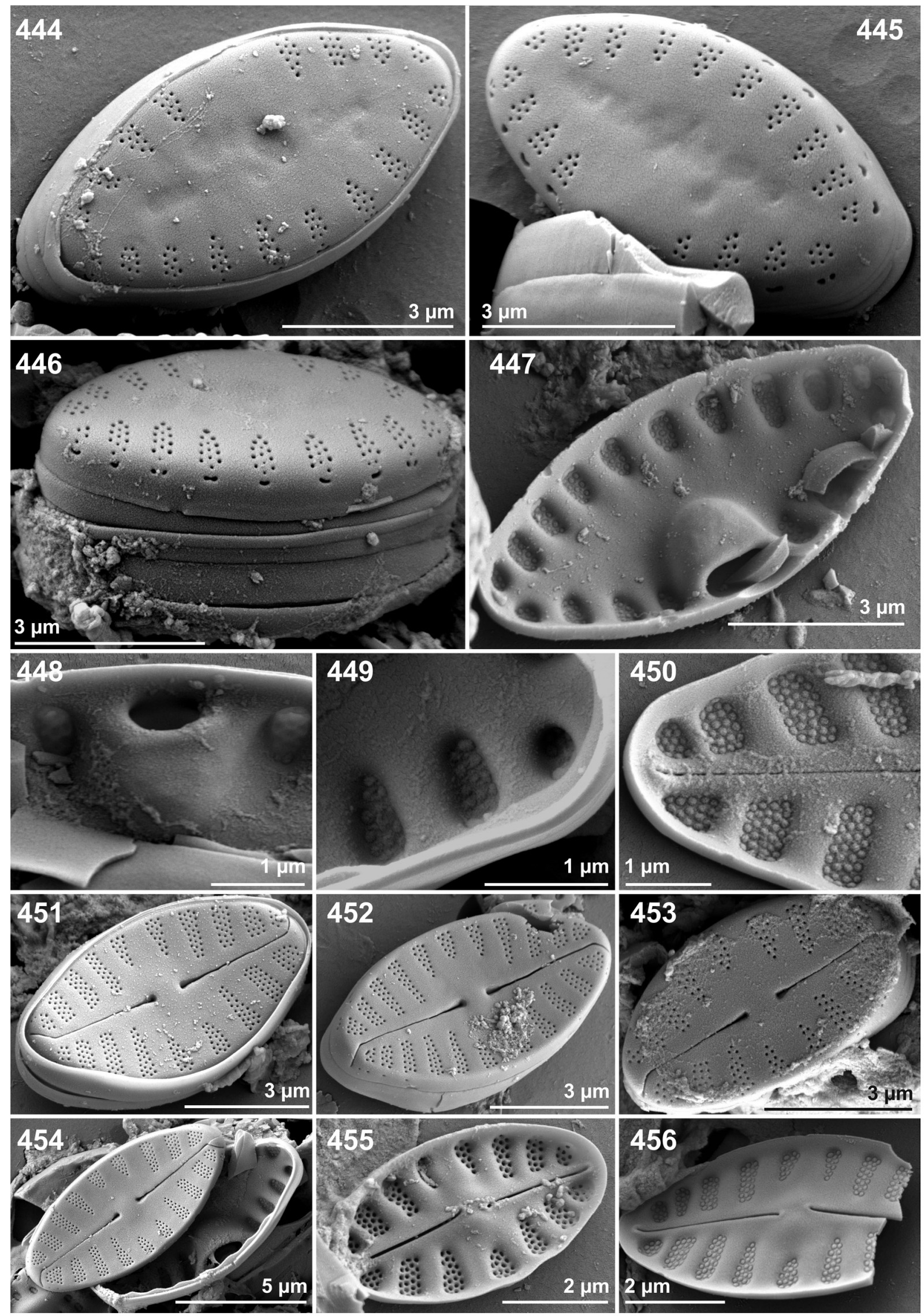

Figs 444-456. Planothidium curtistriatum C.E.Wetzel et Ector sp. nov. Sample from Beaume River at Le Brignon, Auvergne-Rhône-Alpes region (France). Figs 444-446. External view of rapheless valves showing reduced striae and one valve mantle areola. Figs 447-449. Internal views of rapheless valves. Details of striae and narrow cavum aperture. Fig. 450. Internal detail of raphe valve striae and small helictoglossae. Figs 451-454. External raphe valve view showing the variability of the striation pattern. Striae not continuous on the valve mantle. Figs 455 , 456. Internal raphe valve view showing proximal raphe ends and occluded areolae. 


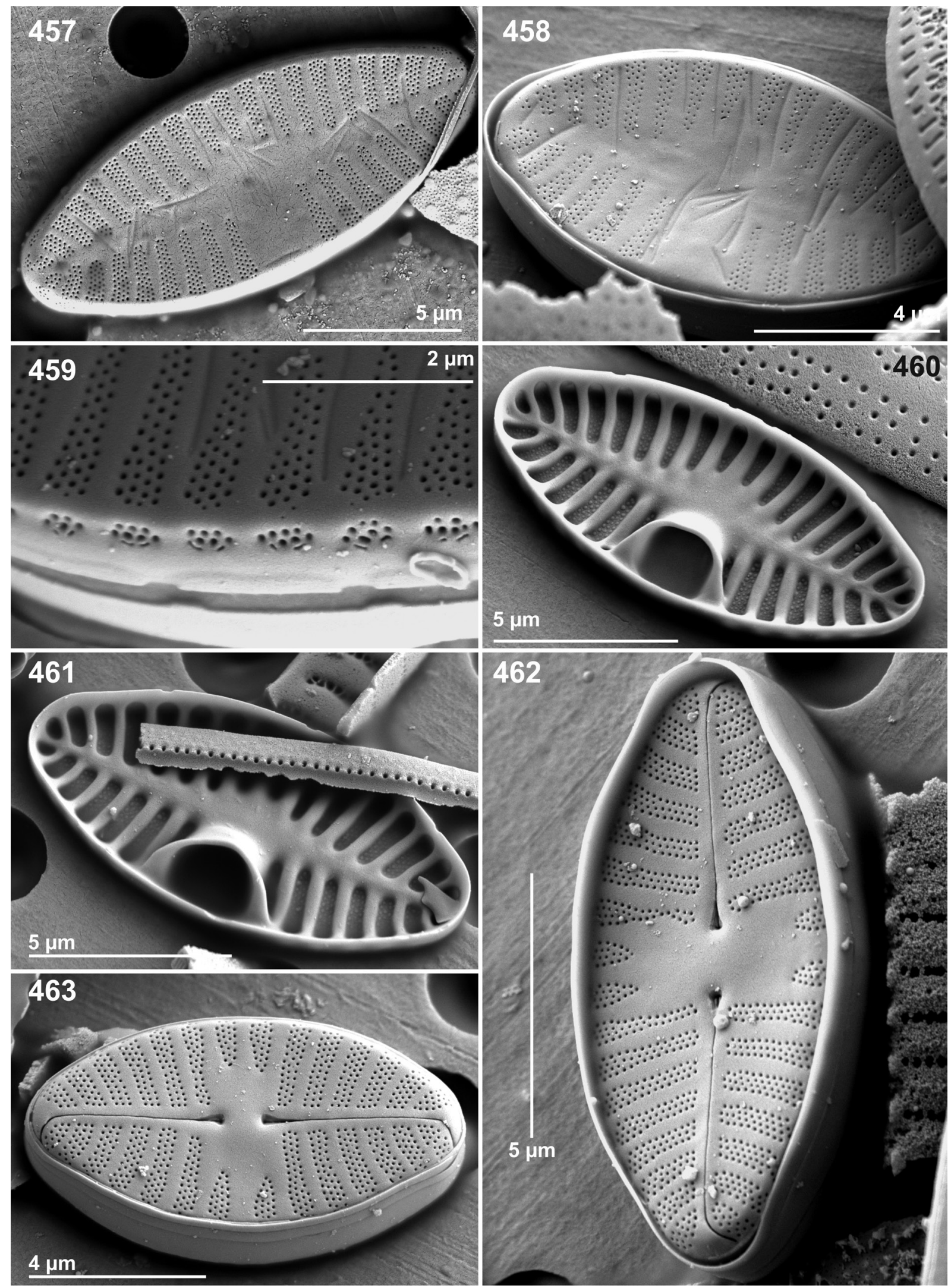

Figs 457-463. Planothidium hinzianum C.E.Wetzel, Van de Vijver et Ector sp. nov. Wümme River, Borgfeld (Germany) Sample E991 in Hustedt Collection. Figs 457, 458. External view of rapheless valve. Fig. 459. Detail of rapheless valve mantle areolae. Figs 460, 461. Internal views of rapheless valves showing wide cavum aperture. Figs 462, 463. External raphe valve showing two short striae near the central area. 


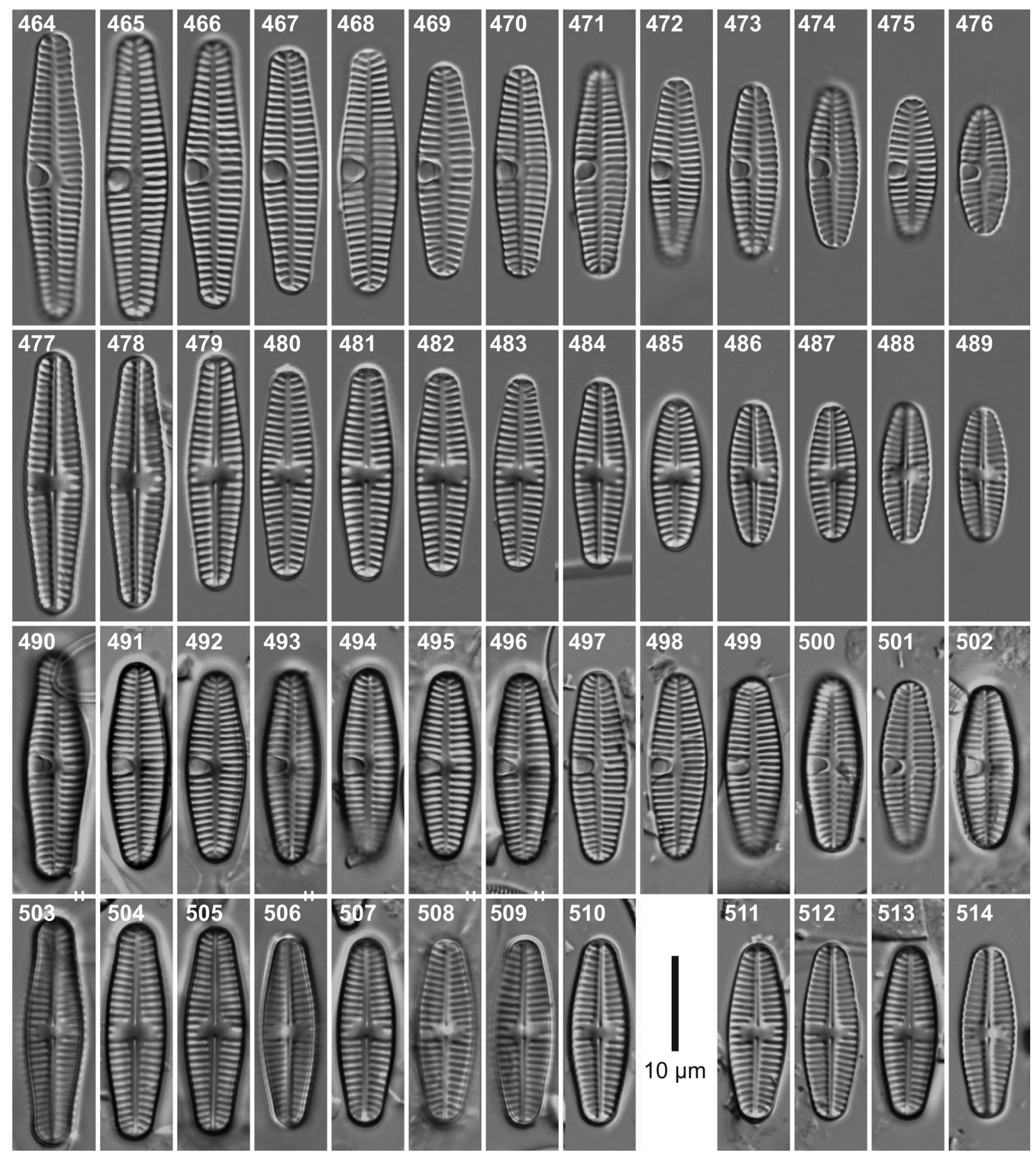

Figs 464-514. Planothidium cavilanceolatum C.E.Wetzel, M.G.Kelly et Van de Vijver sp. nov. Figs 464-489. Population from UK. Figs 490-514. Population from Flanders (Belgium). 

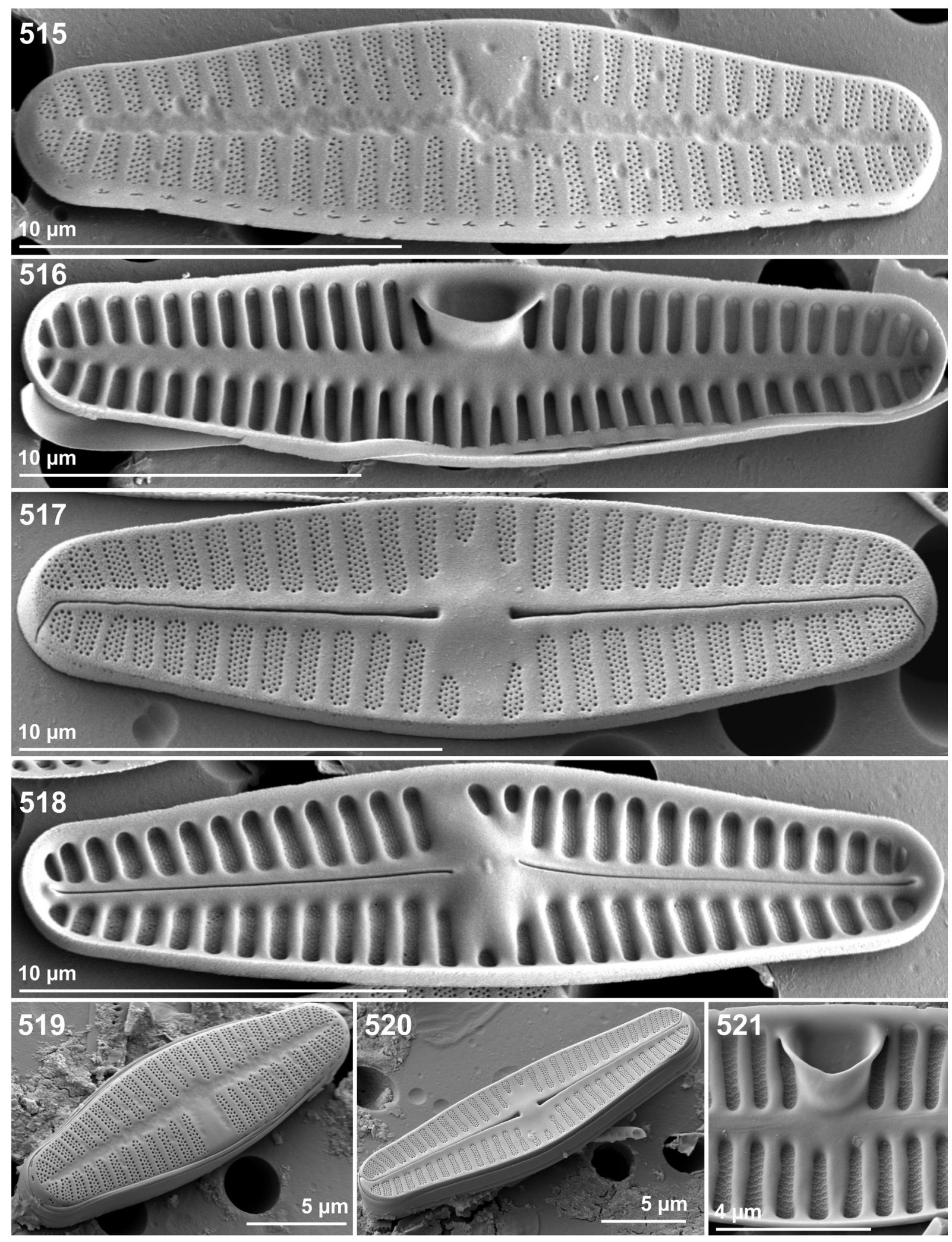

Figs 515-521. Planothidium cavilanceolatum C.E.Wetzel, M.G.Kelly et Van de Vijver sp. nov. Figs 515, 518. Population from UK. Figs 519-521. Population from Flanders (Belgium). External view of an entire rapheless valve (Figs 515, 519). External view of an entire raphe bearing valve showing the external raphe branches, the short terminal fissures and the structure of the striae (Figs 517, 520). Internal view of an entire rapheless valve (Fig. 516). Internal view of an entire raphe bearing valve showing the central area with the proximal raphe endings and the helictoglossa near the valve apex (Fig. 518). Details of wide internal cavum aperture (Fig. 521). 


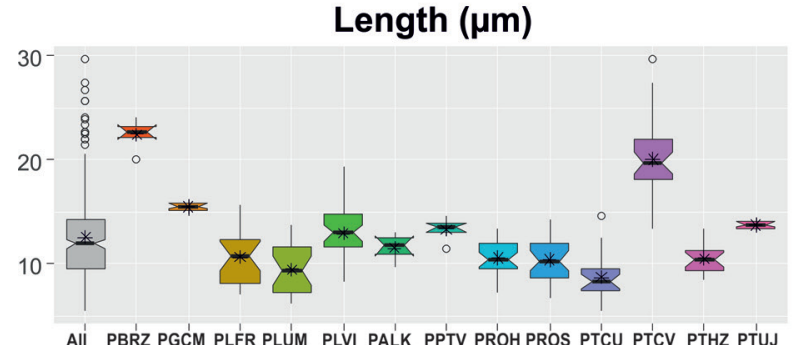

$\mathrm{L}: \mathrm{W}$ ratio

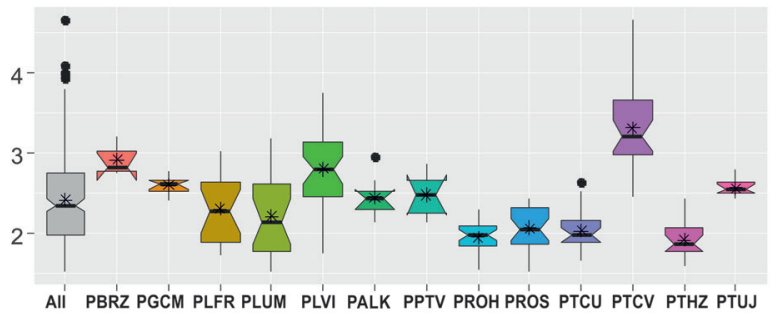

Width $(\mu \mathrm{m})$

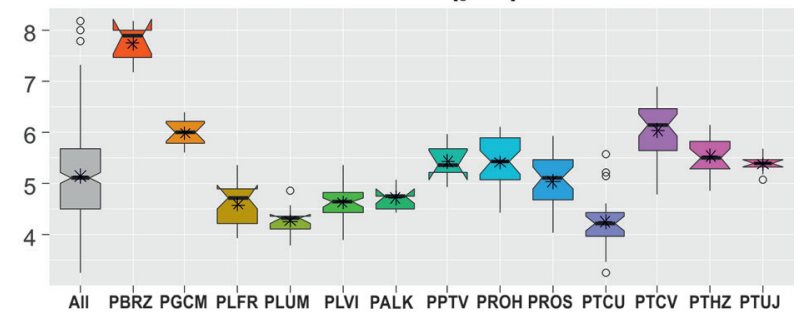

Striae in $10 \mu \mathrm{m}$

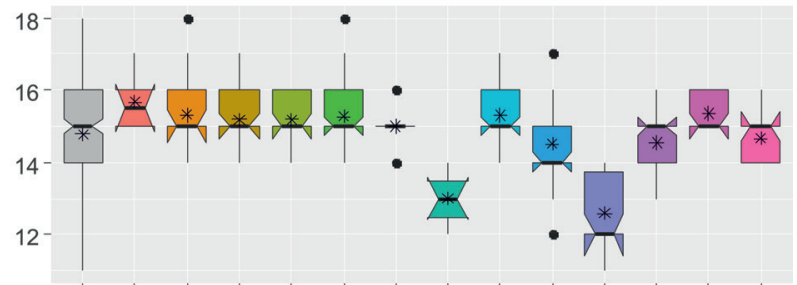

All PBRZ PGCM PLFR PLU'M PLVI PALK PPTV PROH PROS PTCU PTCV PTHZ PTU」

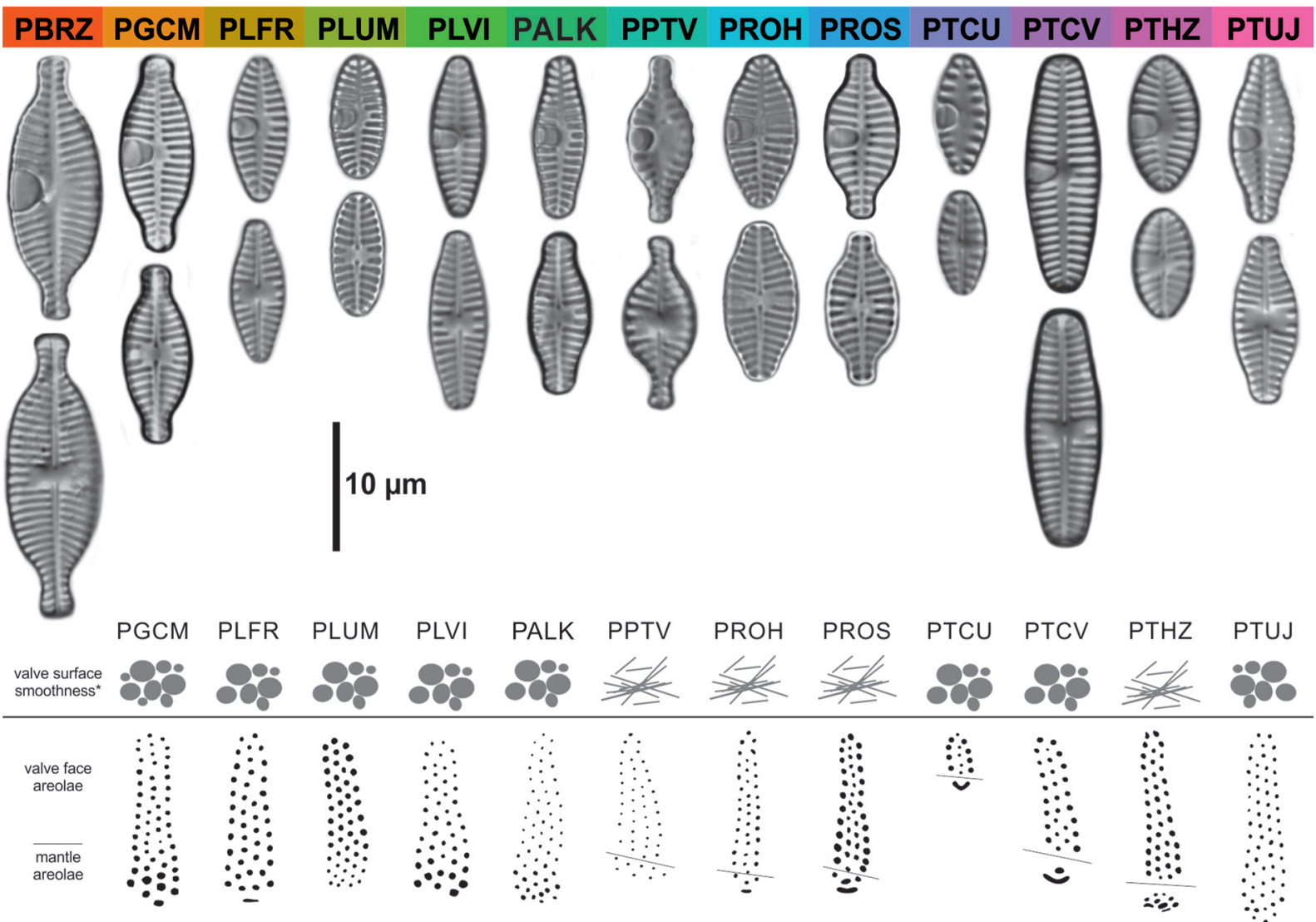

Fig. 522. LM of selected median valves of thirteen Planothidium taxa discussed in the present manuscript. Images from original materials. Basic morphometric values are provided as well as complementary information concerning ultrastructural details such as rapheless valve surface roughness and striation. Interrupting line on the striae scheme denotes interruption of the striae on the valve mantle/face junction. Surface patterns can only be observed in SEM. Four letters accronyms correspond to the following species: Planothidium alekseevae (PALK), P. brasiliense (PBRZ), P. cavilanceolatum (PTCV), P. curtistriatum (PTCU), P. frequentissimum (PLFR), P. gallicum (PGCM), P. hinzianum (PTHZ), P. potapovae (PPTV), P. rostratoholarcticum (PROH), P. rostratum (PRST), P. straubianum (PLUM), P. tujii (PTUJ) and P. victori (PLVI). 